\author{
Marquette University \\ e-Publications@Marquette
}

$2-2013$

\title{
Commercial Property Rent Dynamics in U.S. Metropolitan Areas: An Examination of Office, Industrial, Flex and Retail Space
}

Maria R. Ibanez

University of Chicago

Anthony Pennington-Cross

Marquette University, anthony.pennington-cross@marquette.edu

Follow this and additional works at: https://epublications.marquette.edu/fin_fac

Part of the Finance and Financial Management Commons

\section{Recommended Citation}

Ibanez, Maria R. and Pennington-Cross, Anthony, "Commercial Property Rent Dynamics in U.S. Metropolitan Areas: An Examination of Office, Industrial, Flex and Retail Space" (2013). Finance Faculty Research and Publications. 83.

https://epublications.marquette.edu/fin_fac/83 
Marquette University

e-Publications@Marquette

\section{Finance Faculty Research and Publications/College of Business Administration}

This paper is NOT THE PUBLISHED VERSION; but the author's final, peer-reviewed manuscript. The published version may be accessed by following the link in the citation below.

The Journal of Real Estate Finance and Economics, Vol. 46 (February 2013): 232-259. DOI. This article is (C) Springer and permission has been granted for this version to appear in e-Publications@Marquette. Springer does not grant permission for this article to be further copied/distributed or hosted elsewhere without the express permission from Springer.

\section{Commercial Property Rent Dynamics in U.S. Metropolitan Areas: An Examination of Office, Industrial, Flex and Retail Space}

Maria R. Ibanez

Booth School of Business, The University of Chicago, Chicago, IL Anthony Pennington-Cross

Department of Finance \& Center for Real Estate, College of Business Administration, Marquette University, Straz Hall, Milwaukee, WI

\section{Abstract}

This paper is concerned with the market rental rate for space offered by commercial property and how that rental rate evolves over time. Rental rates reflect the value of the services provided by the property and can have a significant impact on the ability of its owners to make monthly debt obligations. We investigate commercial property rent dynamics for 34 large metropolitan areas in the U.S. The dynamics are studied from 
the second quarter of 1990 through the second quarter of 2009 and the results are compared across four property types or uses (office, industrial, flex, and retail). There is substantial heterogeneity in both the long and short run responses to changing demand and supply conditions. In general, the office market is the slowest to adjust back towards equilibrium while industrial and flex markets adjust back to the long run equilibrium very quickly. For industrial and office types, the speed of adjustment is substantially faster within quality segments and is strongest for grade A properties.

\section{Introduction and Motivation}

This paper focuses on the dynamics of rents, or more specifically, the speed at which rents move back to equilibrium after a supply or demand shock. We examine this speed of adjustment to see if it is faster or slower across different property types (office, retail, etc.), space qualities (grades), magnitude of the disequilibrium, and direction of the disequilibrium (too high or too low).

Most of the prior research about rent dynamics has included only a handful of cities and focused on the office property market. The strength of this paper and its contribution to the literature is that it examines four different property types for a large cross section of metropolitan areas over a reasonable time period. In addition, the paper includes information that covers a broad spectrum of property types ranging from institutional quality property to property at the end if its life cycle. The data was collected from Costar summary reports for 34 of the 50 of the largest metropolitan areas and includes, at most, the second quarter of 1990 through the second quarter of 2009. ${ }^{\text {Footnote1 }}$ This allows us to compare how different property types react to changes in demand and supply conditions in the long run and the speed of adjustment when the market deviates from equilibrium.

Rent dynamics have been studied for many decades, beginning as early as the 1950s when Blank and Winnick (1953) developed a model of the relationship between rents and vacancy rates in the housing market. The basic concept that unoccupied space should have an impact on the rents landlords can charge was more formally tested on local and national US office markets in the 1980s by Shilling et al. (1987) and Wheaton and Torto (1988). Using an error correction model of office rents, Hendershott et al. (2002a) identified long run relationships and the short run dynamic responses to deviations from equilibrium in the same specification. This basic approach has been used in recent papers on office rent dynamics (Brounen and Jennen 2009a; 2009b and

De Francesco 2008) and is the estimation strategy applied in this research. ${ }^{\text {Footnote2 }}$

The relationships between changing demand and supply conditions and rental rates can differ depending on overall economic conditions (for example, expansion versus contraction), the quality of the property, and city size (Brounen and Jennen 2009a and b; Slade 2000). For instance, since it can take a long time to build or modify an office building, if rents are out of equilibrium due to a supply or demand shock, it may take a long time for the supply of space to increase or decrease so that rents return to equilibrium. By contrast, a strip retail mall can be built or renovated in a matter of months and, therefore, correction back to the long run equilibrium could be faster. The types and lengths of lease contracts may also affect the speed at which a property type or even a region returns to equilibrium.

Consistent with this, the development literature finds that the amount and speed of development is affected by the volatility of demand and the extent to which the investment in the development is sunk or irreversible (Bulan et al. 2009; Holland et al. 2000; Schwartz and Torous 2007). For example, flex space is partially reversible precisely because the use of the space is "flexible". Typically, the flexibility is limited to class B or C office space and warehousing or light industry. Nonetheless, this characteristic makes flex space capable of responding when market conditions favor one segment of the commercial market over another. 
There exists theoretical and empirical evidence that rents go down when vacancy rates increase (Wheaton et al. 1997) and employment decreases. There is also persistence in rental rates (Brounen and Jennen 2009a, for office space). Table 1 summarizes the results of prior papers that are most similar to the approach used in this paper (Brounen and Jennen 2009b; Hendershott et al. 2002a; $b$ and 2010). These papers find strong evidence that locations with more office-related employment are associated with higher office rents in the long run and increases in rents in the short run. Similar results are found for retail space using consumer expenditures as the proxy for demand. The evidence on the relationship between rents and the supply of space is not as clear. The impact of occupied supply is consistently negative in the long run, though not always significant, and insignificant in the short run. For example, Brounen and Jennen (2009a) find a negative impact in the long run and a positive impact in the short run for a panel of 15 metropolitan areas in the US using a Torto Wheaton Research (TWR) rent index. ${ }^{\text {Footnote3 }}$ 
Table 1 Results of previous research

\begin{tabular}{|c|c|c|c|c|c|c|c|c|c|c|}
\hline & $\begin{array}{l}\text { Long run } \\
\text { model }\end{array}$ & & & & $\begin{array}{l}\text { Short run } \\
\text { model }\end{array}$ & & & & & \\
\hline & Demand & Supply & & & Demand & & Supply & & $\mathbf{u}_{(\mathrm{t}-1)}$ & $\Delta \ln R_{(t-1)}$ \\
\hline & Employ. & $\begin{array}{l}\text { Occupied } \\
\text { Space }\end{array}$ & $\begin{array}{l}\text { Occupied } \\
\text { Rate }\end{array}$ & Space & Employ. & $\begin{array}{l}\text { Occupied } \\
\text { Space }\end{array}$ & $\begin{array}{l}\text { Occupied } \\
\text { Rate }\end{array}$ & Space & & \\
\hline \multicolumn{11}{|l|}{ Office } \\
\hline \multicolumn{11}{|l|}{$\begin{array}{l}\text { Brounen and } \\
\text { Jennen, 2009b }\end{array}$} \\
\hline $\begin{array}{l}\text { National premier } \\
\text { tier }\end{array}$ & $1.53^{*}$ & -0.34 & & & $2.30^{* *}$ & -0.19 & & & $-0.43 *$ & $0.46^{*}$ \\
\hline Local premier tier & $1.45^{*}$ & -0.26 & & & $1.32^{* *}$ & -0.15 & & & $-0.46 *$ & $0.46^{*}$ \\
\hline $\begin{array}{l}\text { National second } \\
\text { tier }\end{array}$ & $1.12^{*}$ & $-0.52^{*}$ & & & $1.38^{* *}$ & 0.12 & & & $-0.45 *$ & $0.31^{*}$ \\
\hline Local second tier & $0.96^{* *}$ & $-0.37 * *$ & & & $0.88^{* * *}$ & 0.22 & & & $-0.45^{*}$ & $0.34^{*}$ \\
\hline $\begin{array}{l}\text { Hendershott, } \\
\text { MacGregor, and } \\
\text { Tse, 2002a }{ }^{2}\end{array}$ & $\begin{array}{l}(2.89 \text { to } \\
3.84)^{* * *}\end{array}$ & $-4.14 * * *$ & $-4.31 * *$ & $\begin{array}{l}(-4.21 \text { to } \\
-1.87)^{* * *}\end{array}$ & $\begin{array}{l}(3.37 * * * \\
\text { to } 1.14)\end{array}$ & -1.72 & -2.00 & $\begin{array}{l}(1.70 \text { to } \\
1.99)\end{array}$ & $\begin{array}{l}(-0.95 \text { to }- \\
0.87) * * *\end{array}$ & \\
\hline \multicolumn{11}{|l|}{$\begin{array}{l}\text { Hendershott, } \\
\text { MacGregor, and } \\
\text { White, 2002 } \mathrm{b}^{3}\end{array}$} \\
\hline London & 1.25 & & & $-2.78 * * *$ & $4.20 * * *$ & & & 0.77 & -0.04 & \\
\hline $\begin{array}{l}\text { London with } \\
\text { lagged rent (sr) }\end{array}$ & & & & & $2.69 * *$ & & & 0.91 & $-0.19 * *$ & $0.50 * *$ \\
\hline $\begin{array}{l}\text { All regions except } \\
\text { London }\end{array}$ & $0.59 * * *$ & & & $-0.78 * * *$ & $1.14 * * *$ & & & 0.24 & $-0.11 * * *$ & $0.50 * *$ \\
\hline \multicolumn{11}{|l|}{$\begin{array}{l}\text { Hendershott, Lizieri } \\
\text { and MacGregor, } \\
2010^{4}\end{array}$} \\
\hline $\begin{array}{l}\text { Over the 1977- } \\
1996 \text { period }\end{array}$ & $3.02 * * *$ & & & $-5.22 * * *$ & $2.82 * * *$ & & & & -1.30 & $-0.86 * * *$ \\
\hline $\begin{array}{l}\text { Over the 1977- } \\
2006 \text { period }\end{array}$ & $1.90 * * *$ & & & $-4.95 * * *$ & $2.24 * * *$ & & & & $-2.39 * *$ & $-0.44 * *$ \\
\hline Retail & $\begin{array}{l}\text { Consum. } \\
\text { Expend. }\end{array}$ & $\begin{array}{l}\text { Occupied } \\
\text { Space }\end{array}$ & $\begin{array}{l}\text { Occupied } \\
\text { Rate }\end{array}$ & Space & \begin{tabular}{|l} 
Consum. \\
Expend
\end{tabular} & $\begin{array}{l}\text { Occupied } \\
\text { Space }\end{array}$ & $\begin{array}{l}\text { Occupied } \\
\text { Rate }\end{array}$ & Space & & \\
\hline
\end{tabular}




\begin{tabular}{|c|c|c|c|c|c|c|}
\hline $\begin{array}{l}\text { Hendershott, } \\
\text { MacGregor, and } \\
\text { White, 2002b }\end{array}$ & & & & & & \\
\hline London & $1.58 * * *$ & $-3.48 * * *$ & $1.55 * * *$ & $-3.54^{*}$ & $-0.36 *$ & \\
\hline $\begin{array}{l}\text { London with } \\
\text { lagged rent (sr) }\end{array}$ & & & $0.98 * *$ & $-3.10 * *$ & $-0.46 * *$ & $0.43 * * *$ \\
\hline $\begin{array}{l}\text { All regions except } \\
\text { London }\end{array}$ & $1.11^{* * *}$ & $-0.74 * * *$ & $1.46^{* * *}$ & $-0.53 * *$ & $-0.23 * * *$ & \\
\hline
\end{tabular}

${ }^{1}$ Brounen and Jennen (2009b) use annual office market data for the two most important cities in five European countries, distinguishing between premier tier office (London, Madrid, Frankfurt, Paris, and Amsterdam) and second tier office (Glasgow, Barcelona, Düsseldorf, Lyon, and Rotterdam). Their demand driver is FTE (full-time equivalent) employment service industry. ${ }^{2}$ Hendershott et al. (2002a) employ annual City of London office market data. Their demand driver is employment. ${ }^{3}$ Hendershott et al. (2002b) study a 29 years period for ten regions in the UK plus London. Their demand drivers are Finance \& business services employment for office and Consumers Expenditure for retail. ${ }^{4}$ Hendershott et al. (2010) focus on the City of London office markets and include a lagged level of vacancy rates. Here we report the estimation results for the symmetric rent models. "Emlpoy" stands for employment and "consum expend" stands for consumer expenditure. *s indicate statistical significance of the coefficient estimate: * for $10 \%$, $* *$ for $5 \%$, and $* * *$ for $1 \%$ 
Hendershott et al. (2002b) conclude that the demand elasticities for retail and office spaces are similar in the United Kingdom. Furthermore, they find no significant difference between North and South in terms of growth regions, although they do find what they call the "London effect", that is, the demand elasticity for space with respect to both price (rent) and income are much lower in magnitude in London than in the rest of the United Kingdom.

Brounen and Jennen (2009a) extend the analysis by testing asymmetry in rent response to positive changes in office employment. Positive office employment changes have a significantly higher impact on rents when occupancy is elevated (vacancy rates below the long-term mean). Additionally, they find a very slow error correction. Within a year, only about $4.5 \%$ of the disequilibrium in rents is restored.

Englund et al. (2008) introduce the concept of "hidden vacancies" - unobservable deviations of the occupied space from the current demand, which are a temporary consequence of the rigidities in the market and can be positive or negative. The market refers to this as the sublet market for space. Hence, occupied space does not represent the actual demand for space. Hidden vacancies refer to that space that is currently occupied only because of moving/transaction costs and stable lease terms, but would be vacant ("open vacancies") otherwise. If the renter enjoys an historic (previously set) rental rate that is lower than the current market rate, due to multi-period lease contracts, the space could have been vacant had the contract been updated. Information from Costar indicates that this issue may be more important in office property than in retail property. ${ }^{\text {Footnote4 }}$

The remainder of the paper reviews the error correction empirical model, presents the data, introduces the empirical results, and provides a discussion of the results and conclusion.

\section{The Hendershott and Coauthors Error Correction Model}

Hendershott et al. (2002b) observed that the prior literature modeled the property market through either a reduced form demand-supply equation, identified as the European style, or an equilibrium-based rental adjustment equation, identified as the US style. They combine both of these approaches or styles in an error correction model (ECM), which takes into account dynamics and long term trends of the property markets. Starting from the long run equilibrium relationships, one can use the error term from this original specification to proxy for the disequilibrium responses. This proxy is called an error correction term and is subsequently lagged and included in the short run or differenced model to account for how far from equilibrium the market is.

We present an ECM of commercial property rents following Hendershott et al. (2002b) and the literature that follows (Brounen and Jennen 2009a and $b$ and De Francesco 2008). ${ }^{\text {Footnote5 }}$ The demand for space (D) can be modeled as a function of rents $(R)$ along with the economic activity $(E)$ in a Cobb-Douglas function:

$D=\lambda_{0} R^{\lambda_{1}} E^{\lambda_{2}}(1)$

The "price" (rent) elasticity $\left(\lambda_{1}\right)$ is expected to be negative, while the income elasticity $\left(\lambda_{2}\right)$ should be positive. The occupied supply of space (OS) can be expressed as the product of the supply of available office space $(s)$ and the occupancy rate, (1-v), in which $v$ stands for vacancy rate.

$O S=(1-v) S(2)$

By definition, the demand of space equals the occupied supply of space:

$D(R, E) \equiv O S(v, s)(3)$

Taking logs on both sides of the equation and solving for the log of rent gives the reduced-form long run model: $\ln R_{i t}=\beta_{0}+\beta_{1} \ln E_{i t}+\beta_{2} \ln \left[\left(1-v_{i t}\right) \times s_{i t}\right]+u_{i t}(4)$ 
This equation shows long run price (rent) as a reflection of supply and demand. The $i$ subscript identifies the metropolitan area or cross section, while the $t$ subscript stands for time and denotes the observation for the particular panel. Here, $u_{i t}$ is the error term. The implied price and income elasticity are $\lambda_{1}=1 / \theta_{2}$ and $\lambda_{2}=$ $-b_{1} / b_{2}$, respectively. Under this specification, rents are associated with contemporaneous demand and supply variables. The contemporaneous vacancy rate is likely to be endogenous, as higher unemployment leads to lower commercial occupancies and declining rents. Following Grenadier (2005) and Brounen and Jennen (2009b), we estimate the vacancy rate, $v^{\wedge} v^{\wedge}$, from a simple autoregression model. We choose the optimal lag order according to the Akaike Information Criterion (AIC) statistics for each metropolitan area and each property type.

For the price and income elasticity to be of correct sign in the long run model, the coefficient on occupied space must be negative. This implies that higher vacancy rates, which must decrease the amount of occupied space, $\left(\left(1-\hat{v}_{i t}\right) \times s_{i t}\right)$, should be associated with higher rent rates. This relationship seems problematic. One approach taken in the literature is to break occupied space or supply into its two components, the occupancy rate and total space.

Due to inconsistent empirical results in the literature and in this paper's results we will test a variety of proxies for supply. First, we test the supply specification using occupied space, then separate vacancy and the supply of space, and lastly only include space (both occupied and unoccupied) as the measure of supply. In fact, since vacancy reflects the interaction of supply and demand conditions it is neither a proxy for supply nor a proxy for demand.

The ECM requires the variables in the level equation to be cointegrated, or the error correction term to be stationary. Taking differences of the level equation and adding the error correction term yields the short run rent adjustment model:

$\Delta \ln R_{i t}=\alpha_{0}+\alpha_{1} \Delta \ln E_{i t}+\alpha_{2} \Delta \ln \left[\left(1-\hat{v}_{i t}\right) \times s_{i t}\right]+\alpha_{3} u_{i(t-1)}+\alpha_{4} \Delta \ln R_{i(t-1)}+\varepsilon_{i t}(5)$

Here $\Delta$ is the differencing operator, such that $\Delta y_{i, t}=y_{i, t}-y_{i, t-1}, u_{i(t-1)}$ is the error-correction term estimated from the long run model, and $\varepsilon_{i t}$ is the error term. The ECM requires the variables in the level equation to be cointegrated, or the error correction term to be stationary, so we perform unit root test on the error term as a preliminary step. The rents adjust to short run changes in the state of the economy, the vacancy rate, the supply of space, deviations of rents from their long run values (error correction term or lagged error term from the long run model), and the lagged rent changes. The lagged endogenous variable, $\Delta \ln R_{(t-1)}$, allows for partial short run adjustment in the rents or sticky rents (De Wit and Van Dijk 2003). Assuming that there is no drift in rents, $\alpha_{o}$ should be zero. If rents are sticky, then changes in demand, measured by employment or sales, should lead to an increase in rents. The impact of changes in occupied stock is indeterminate. The coefficient on the error correction model is expected to be negative, and it indicates whether there is no adjustment $\left(\alpha_{3}=0\right)$, partial adjustment $\left(-1<\alpha_{3}<0\right)$, complete adjustment $\left(\alpha_{3}=-1\right)$, or over-adjustment $\left(\alpha_{3}<-1\right)$.

\section{Data}

Demand drivers considered by the literature include consumer expenditures, industry-specific employment and output (for example, for financial and business services or manufacturing), unemployment rate, value added of office-related industries, and gross domestic product (Hendershott et al. 2002a and b; De Francesco 2008;

Brounen and Jennen 2009a and b). In this paper we use property type and metro area specific employment. ${ }^{\text {Footnote6 }}$ For retail space, we include national retail sales as a proxy for economic activity. Sales, in trillions, for each property type are from the Monthly Retail Trade Survey, reported by the U.S. Census Bureau. ${ }^{\text {Footnote7 }}$ 
Table 2 describes the variables. Average asking rents and vacancy rates for each metropolitan area and property type are obtained from CoStar quarterly summary reports. Office rents are reported as full-service or gross, while retail, flex, and industrial rents are reported as NNN. ${ }^{\text {Footnote8 }}$ Costar is one of the largest providers of commercial real estate information to the market place. Costar reports that the database contains more than 77 billion square feet of inventory, 1.5 million listings, and 10.6 million images of the property. The primary client for Costar is commercial brokers. Costar collects its information by asking property owners, brokers, and local government officials for information describing the building and the lease that is being marketed. Individuals can enter a listing onto the system and Costar independently verifies the listing. Costar is not compensated based on successful transactions. While not identical, Costar does resemble the single family market multiple listing service run by the National Association of Realtors. However, Costar is a for profit company listed on NASDAQ with a ticker of CSGP.

\section{Table 2 Description of variables}

\begin{tabular}{|l|l|}
\hline Variable & Description \\
\hline$R$ & $\begin{array}{l}\text { Real rent (in } 1990 \text { constant dollars) per square foot per year for each metropolitan area (as defined } \\
\text { by the metropolitan area Core Based Statistical Area, CBSA) and property type. Rent is defined as } \\
\text { the total average rate of asking rents for the CBSA and property type. Real rent series is obtained } \\
\text { by dividing nominal rent values by the price index (year 1990) for that same time period set price } \\
\text { indexes equal to } 100 \text { in a given base year. } \Delta R \text { is the growth rate of real rent quarter to quarter (for } \\
\text { example, a 5\% increase is expressed as 0.05) for each CBSA and property type. Source: CoStar } \\
\text { (Nominal Rent) and U.S. Bureau of Labor Statistics (Consumer Price Index, CPI). }\end{array}$ \\
\hline$v$ & $\begin{array}{l}\text { Percentage of total space (rentable building area) vacant for each CBSA and property type. Source: } \\
\text { CoStar. }\end{array}$ \\
\hline$\hat{v}$ & $\begin{array}{l}\text { Estimated vacancy rate from an autoregression model. The lag length is determined by the Akaike } \\
\text { Information Criterion (AIC) statistics for each CBSA and each property type. Source: CoStar and } \\
\text { author calculations. }\end{array}$ \\
\hline$s$ & $\begin{array}{l}\text { Square feet of available space (supply) or rentable building area (RBA) in each quarter for each } \\
\text { CBSA and property type. The total square footage of the buildings that can be occupied by, or } \\
\text { assigned to a tenant for the purpose of determining a tenant's rental obligation. Generally, RBA } \\
\text { includes a percentage of common areas including all hallways, main lobbies, bathrooms, and } \\
\text { telephone closets. }\end{array}$ \\
\hline$Q$ & Source: CoStar. \\
\hline$E$ & Sales, in trillions of dollars, seasonally adjusted for each property type. Source: U.S. Census Bureau. \\
\hline & $\begin{array}{l}\text { All Employees, in thousands, uniformly weighted moving average including } 3 \text { lagged terms and the } \\
\text { current observation, for each CBSA and property type. Source: U.S. Bureau of Labor Statistics and } \\
\text { author calculations. }\end{array}$ \\
\hline
\end{tabular}

Like most data sets, Costar data is not perfect, but it does provide a unique view of commercial property because it is not limited to investment grade property (it includes anyone marketing property). It is available for "top tier" cities on the coast such as Washington DC and Los Angeles as well as smaller Midwest markets such as Columbus $\mathrm{OH}$ and southern areas such as Memphis TN. As a result, there is a lot of cross sectional variation in the data set and many of the properties are of lower quality. For example, the average size of industrial property in the estimation data set is approximately 41,500 square feet. If the data is separated into different grades, grade $A$ industrial property is on average 172,352 square feet and grades $B$ and $C$ are respectively 62,858 and 29,569 . This is evidence that the Costar data provides very broad coverage in market segments that are less likely to be of interest to institutional investors but are still important parts of the property market. 
While the Costar data provides broad market coverage, it does not come without some limitations. A study of rent dynamics would ideally use a constant quality rent series and the rent series should reflect the true cost of renting. Relative to constant quality rents, average rents should tend to rise as the quality on average improves and decrease as the average quality deteriorates. If property quality is pro-cyclical then this should increase the volatility of the average rent series. To estimate the effective or true rent from a lease, the length of the lease, any incentives given to the tenant to move in (lower cost tenant improvements, first month free, etc....), the nature of expense reimbursements, and any future changes in the rental rate must all be known. ${ }^{\text {Footnote9 }}$ This is a very detailed and difficult task that requires projections of indexes and property specific operating expenses. Costar summary quarterly reports do not report this information. Therefore, asking rents are likely to be smoother than effective rents because concessions tend to be more frequent when the market is in decline. ${ }^{\text {Footnote10 }}$

Upon examination of the rent and vacancy time series, it became clear that when a new metropolitan area is added to the Costar data series the initial data are often extremely volatile. This may be attributable to survey start up issues. Therefore, for most metropolitan areas the first few observations are removed from the sample. Table 3 reports the time period when the rent data is available by metropolitan area and property type.

Table 4 provides summary statistics for each property type of the data set used in this analysis. The data covers thirty-four metropolitan areas for at most a period of 1990:Q2 through 2009:Q2, and is classified by property type (office, retail, industrial and flex).

Table 3 Data availability by metropolitan area and property type

\begin{tabular}{|l|l|l|l|l|}
\hline Metropolitan area & Office & Retail & Industrial & Flexible \\
\hline Atlanta-Sandy Springs-Marietta, GA & $1990 q 2$ & $2001 q 2$ & $1992 q 2$ & $1992 q 2$ \\
\hline Austin-Round Rock, TX & $2002 q 2$ & $2001 q 2$ & $2001 q 1$ & $2002 q 2$ \\
\hline Baltimore-Towson, MD & $1999 q 2$ & $2001 q 2$ & $1994 q 2$ & $1994 q 2$ \\
\hline Charlotte-Gastonia-Concord, NC-SC & $2000 q 4$ & $2001 q 2$ & $2000 q 2$ & $2000 q 2$ \\
\hline Chicago-Naperville-Joliet, IL-IN-WI & $1999 q 2$ & $2001 q 2$ & $1996 q 3$ & $1996 q 3$ \\
\hline Cincinnati-Middletown, OH-KY-IN & $2000 q 2$ & $2001 q 2$ & $2000 q 2$ & $2000 q 2$ \\
\hline Cleveland-Elyria-Mentor, OH & $2000 q 2$ & $2001 q 2$ & $2000 q 2$ & $2000 q 2$ \\
\hline Columbus, OH & $2000 q 2$ & $2001 q 2$ & $2000 q 2$ & $2000 q 2$ \\
\hline Dallas-Fort Worth-Arlington, TX & $2000 q 1$ & $2001 q 2$ & $1996 q 2$ & $1996 q 2$ \\
\hline Denver-Aurora, CO & N/A & N/A & N/A & $2000 q 2$ \\
\hline Detroit-Warren-Livonia, MI & $2000 q 3$ & $2001 q 2$ & $2000 q 2$ & $2000 q 3$ \\
\hline Houston-Sugar Land-Baytown, TX & $1999 q 2$ & $2001 q 2$ & $1999 q 2$ & $1999 q 2$ \\
\hline Indianapolis-Carmel, IN & $2000 q 4$ & $2001 q 2$ & $2000 q 4$ & $2001 q 4$ \\
\hline Jacksonville, FL & $2000 q 1$ & $2001 q 2$ & $2000 q 1$ & $2000 q 1$ \\
\hline Kansas City, MO-KS & $2000 q 4$ & $2001 q 2$ & $2000 q 4$ & $2000 q 4$ \\
\hline Los Angeles-Long Beach-Santa Ana, CA & $1997 q 2$ & $2001 q 2$ & $1998 q 1$ & $1997 q 1$ \\
\hline Memphis, TN-MS-AR & $2000 q 2$ & $2001 q 2$ & $2000 q 2$ & $2002 q 2$ \\
\hline Miami-Fort Lauderdale-Pompano Beach, FL & $1999 q 4$ & $2001 q 3$ & $1999 q 4$ & $1999 q 4$ \\
\hline Nashville-Davidson-Murfreesboro-Franklin, TN & $2001 q 1$ & $2001 q 2$ & $2003 q 2$ & $2001 q 1$ \\
\hline New York-Northern New Jersey-Long Island, NY-NJ-PA & $1996 q 4$ & N/A & $1996 q 4$ & $1996 q 4$ \\
\hline Orlando-Kissimmee, FL & $2000 q 3$ & $2001 q 2$ & $2000 q 3$ & $2000 q 2$ \\
\hline Philadelphia-Camden-Wilmington, PA-NJ-DE-MD & $1997 q 4$ & $2001 q 2$ & $1997 q 4$ & $1997 q 4$ \\
\hline Phoenix-Mesa-Scottsdale, AZ & $1999 q 2$ & $2001 q 2$ & $1999 q 2$ & $1999 q 4$ \\
\hline Pittsburgh, PA & $2000 q 4$ & $2001 q 2$ & $2000 q 4$ & $2000 q 4$ \\
\hline
\end{tabular}




\begin{tabular}{|l|l|l|l|l|}
\hline Portland-Vancouver-Beaverton, OR-WA & 2003q2 & $2003 q 2$ & $2003 q 2$ & $2003 q 3$ \\
\hline Raleigh-Cary, NC & $2002 q 2$ & $2001 q 2$ & $2000 q 4$ & $2000 q 4$ \\
\hline Riverside-San Bernardino-Ontario, CA & $1999 q 2$ & $2001 q 2$ & $1998 q 2$ & $1999 q 2$ \\
\hline Sacramento-Arden-Arcade-Roseville, CA & $1999 q 1$ & $2001 q 2$ & $2001 q 3$ & $1999 q 2$ \\
\hline St. Louis, MO-IL & $2000 q 2$ & $2001 q 2$ & $2000 q 3$ & $2001 q 2$ \\
\hline San Diego-Carlsbad-San Marcos, CA & $1999 q 3$ & $2001 q 2$ & $1999 q 3$ & $1999 q 3$ \\
\hline San Jose-Sunnyvale-Santa Clara, CA & $1999 q 3$ & $2001 q 2$ & $1997 q 2$ & $1997 q 3$ \\
\hline Seattle-Tacoma-Bellevue, WA & $2002 q 2$ & $2001 q 2$ & $2000 q 2$ & $2000 q 3$ \\
\hline Tampa-St. Petersburg-Clearwater, FL & $1999 q 4$ & $2001 q 2$ & $2000 q 2$ & $1999 q 4$ \\
\hline Washington-Arlington-Alexandria, DC-VA-MD-WV & $1994 q 1$ & $2001 q 2$ & $1993 q 3$ & $1993 q 3$ \\
\hline
\end{tabular}

All data continues to 2009q2. N/A indicates the data is not available. The metropolitan area is defined as Core Based Statistical Area, CBSA

Table 4 Summary statistics by property type

\begin{tabular}{|l|l|l|l|l|l|}
\hline Variable & Obs & Mean & Std. Dev. & Min & Max \\
\hline Office Date: 1990q2-2009q2 & & & & & \\
\hline Real Rent & 1310 & 14.18 & 3.38 & 8.74 & 37.88 \\
\hline Office Employment & 1310 & $1,025.02$ & 983.53 & 227.30 & $5,228.90$ \\
\hline Vacancy & 1310 & 0.12 & 0.03 & 0.01 & 0.20 \\
\hline Retail Date: 2001q2-2009q2 & & & & & \\
\hline Real Rent & 1047 & 9.89 & 3.32 & 2.02 & 35.11 \\
\hline Real Retail Sales & 1047 & $587,462.40$ & $36,508.62$ & $509,415.60$ & $649,210.80$ \\
\hline Retail Employment & 1047 & 175.47 & 116.79 & 50.00 & 626.30 \\
\hline Vacancy & 1047 & 0.05 & 0.03 & 0.01 & 0.12 \\
\hline Industrial Date: 1992q2-2009q2 & & & & & \\
\hline Real Rent & 1398 & 3.31 & 1.11 & 1.48 & 12.97 \\
\hline Industrial Employment & 1398 & 180.50 & 170.11 & 29.60 & 885.60 \\
\hline Vacancy & 1398 & 0.08 & 0.03 & 0.02 & 0.16 \\
\hline Flexible Date: 1992q2-2009q2 & & & & & \\
\hline Real Rent & 1392 & 6.39 & 1.95 & 2.93 & 24.25 \\
\hline Flexible Employment & 1392 & $1,203.38$ & $1,104.15$ & 260.40 & $5,671.00$ \\
\hline Vacancy & 1392 & 0.13 & 0.04 & 0.01 & 0.27 \\
\hline
\end{tabular}

Obs is the number of observations. Std. Dev. stands for standard deviation

Figure 1 depicts national average rents for our sample of 34 metropolitan areas. The rents are compared to the vacancy rate, sales and the change in the natural log of employment. The figure indicates that when office vacancy rates were low and office-based employment was growing, real rents were increasing. It is of some interest that when employment was declining and vacancy rates were increasing very quickly in 2008, rents had not yet started declining. This may reflect the relative slowness with which the office market can react to changing economic conditions due to the long-term nature of most office leases and more frequent use of the sublet market. For retail property it is difficult to see any obvious cycles. However, sales and rents seem to move together over time. Rents rise steadily through the mid 2000s and stabilize in 2007 despite consistently increasing vacancy rates. In the industrial market vacancy rates and employment growth move almost in synchronicity, but employment has been in decline through most of the 2000 s leading to almost a $50 \%$ 
reduction in industrial rents. Similar to the industrial market, the flex market experienced strong rental growth in the 1990s but substantial erosion in the 2000s.
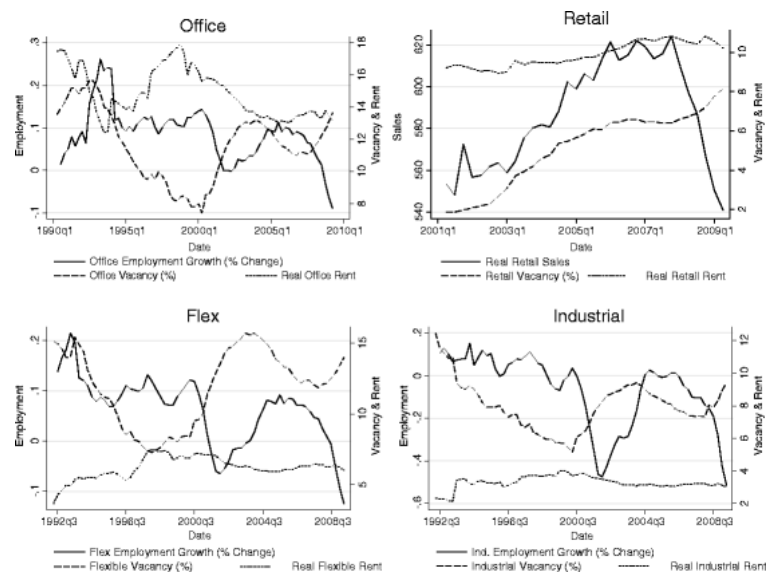

Fig. 1 Aggregate time series by property type. National averages, aggregated from CBSA level data. To scale it for graphical purposes Vacancy is multiplied by 100 to express as a percentage and Sales is divided by 1,000

Since asking rental rates are likely to be smoother than effective rents, it might be useful to compare the Costar asking rent changes to TWR rent changes. ${ }^{\text {Footnote11 }}$ For office property, rents declined approximately 4, 7, and 7\% per year in 2001 through 2003 for the TWR index. Nominal Costar asking rents declined 1, 4, and 5\% for the same time period. For industrial property, TWR rents are estimated to decline by 1,3 , and $3 \%$ in 2001,2002 , and 2003. Nominal Costar asking rents decline 7,4 , and $4 \%$ over the same time periods. Therefore, while there may be some smoothing of the Costar asking rents they do follow the same general pattern as the TWR modeled rents and sometimes decrease more and other times decrease less. Footnote12

The figures reinforce the important relationships between rents, vacancy and economic activity. In general and not surprisingly, rent appreciation seems to be associated with lower vacancy rates and growing employment. Similar associations are found for office, retail, industrial, and flex property types.

\section{Empirical Results}

\section{Pooled Results}

Panel I of Tables 5 and 6 report the results from estimating Eqs. 4 and 5 for each property type. A measure of metropolitan area economic activity (EA) is included in each specification as the proxy for demand. For office, industrial, and flex space, industry specific employment is used as the proxy. For retail space, national retail sales are used as the demand proxy. Occupied space, $\ln [(1-\hat{v}) \times s]$, is calculated using a fitted vacancy rate, $\hat{v}$, and all (occupied and unoccupied) space, $s$. The fitted values $(\hat{v})$ of vacancy rates are estimated in a separate autoregressive model for each metropolitan area. Based on the Akaike information criterion (AIC) statistics for each metropolitan area and each property type, the optimal lag order for vacancy rate is one or two lags in most cases, with some exceptions at three, four and five lags.

Table 5 Pooled long run results

\begin{tabular}{|l|l|l|l|l|}
\hline & Office & Retail & Industrial & Flex \\
\hline I. Occupied space & & & & \\
\hline $\ln ($ EA $)$ & 0.290 & $0.722^{* *}$ & $0.498^{* * *}$ & $1.310^{*}$ \\
\hline & $(0.882)$ & $(0.289)$ & $(0.155)$ & $(0.667)$ \\
\hline
\end{tabular}




\begin{tabular}{|l|l|l|l|l|}
\hline $\operatorname{In}[(1-\hat{v}) \times \mathrm{s}]$ & -0.408 & $1.178^{* * *}$ & 0.191 & -0.341 \\
\hline & $(0.925)$ & $(0.370)$ & $(0.162)$ & $(0.403)$ \\
\hline$R^{2}$-adj & 0.809 & 0.746 & 0.893 & 0.742 \\
\hline$N$ & 1310 & 1047 & 1398 & 1392 \\
\hline Wooldridge & 184.063 & 95.945 & 20.658 & 69.285 \\
\hline II. Vacancy rate and space separated & & & & \\
\hline $\operatorname{In}($ EA) & 0.189 & 0.156 & $0.347^{* *}$ & $1.322^{* *}$ \\
\hline & $(0.652)$ & $(0.200)$ & $(0.137)$ & $(0.585)$ \\
\hline $\ln (\hat{v})$ & $-0.161^{* * *}$ & 0.092 & $-0.150^{* * *}$ & -0.079 \\
\hline & $(0.039)$ & $(0.060)$ & $(0.033)$ & $(0.048)$ \\
\hline $\operatorname{In}(\mathrm{s})$ & -0.269 & 0.443 & 0.106 & -0.459 \\
\hline & $(0.656)$ & $(0.409)$ & $(0.136)$ & $(0.421)$ \\
\hline$R^{2}$-adj & 0.846 & 0.763 & 0.900 & 0.755 \\
\hline$N$ & 1310 & 1047 & 1398 & 1392 \\
\hline Wooldridge & 230.206 & 86.039 & 20.723 & 71.623 \\
\hline III. No vacancy rate & & & & \\
\hline $\operatorname{In}($ EA) & 0.896 & $0.491^{*}$ & $0.492^{* * *}$ & $1.572^{* *}$ \\
\hline & $(0.602)$ & $(0.240)$ & $(0.164)$ & $(0.614)$ \\
\hline $\operatorname{In}(\mathrm{s})$ & $-1.113^{*}$ & $1.045^{* * *}$ & 0.108 & -0.699 \\
\hline & $(0.609)$ & $(0.268)$ & $(0.155)$ & $(0.459)$ \\
\hline$R^{2}$-adj & 0.833 & 0.754 & 0.893 & 0.752 \\
\hline$N$ & 1310 & 1047 & 1398 & 1392 \\
\hline Wooldridge & 237.399 & 90.981 & 20.661 & 71.961 \\
\hline
\end{tabular}

This table reports the results from the error correction model of different property types' rents $(R)$ for 33 (office), 32 (retail), or 34 (industrial, flex) CBSAs, considering all quality grades ( $A, B$ and $C$ ). All models are measured including a constant term and binary variables for each metropolitan area (estimated coefficients not shown), omitting Atlanta-Sandy Springs-Marriett, GA. The dependent variable is $\ln (R)$ and $\Delta \ln (R)$ for long and short run models, respectively. $R$ stands for real rent, $E A$ is sector specific employment for office, industrial, and flex property types and retail sales for the retail property type, $v$ is the fitted vacancy rate, and $s$ is the sector specific stock of space. $\mathrm{N}$ is the number of observations. Wooldridge is the Wooldridge test for autocorrelation in panel data. In all cases, the p-value is 0.000 , so the null hypothesis of no serial correlation is strongly rejected. Robust standard error (adjusted for clusters in CBSA) statistics appear in parenthesis. ${ }^{*} p=0.10,{ }^{* *} p=0.05$, $* * * p=0.01$

Table 6 Pooled short run results

\begin{tabular}{|l|l|l|l|l|}
\hline & Office & Retail & Industrial & Flex \\
\hline I. Occupied space & & & & \\
\hline$\Delta \ln (\mathrm{EA})$ & $0.942^{* *}$ & $0.322^{* *}$ & 0.615 & $1.795^{* *}$ \\
\hline & $(0.411)$ & $(0.137)$ & $(0.369)$ & $(0.773)$ \\
\hline$\Delta \ln [(1-\hat{v}) \times s]$ & 0.100 & 0.092 & -0.304 & -0.284 \\
\hline & $(0.126)$ & $(0.337)$ & $(0.256)$ & $(0.212)$ \\
\hline $\mathrm{u}_{(\mathrm{t}-1)}$ & $-0.038^{* * *}$ & $-0.156^{* * *}$ & $-0.194^{* * *}$ & $-0.169^{* * *}$ \\
\hline & $(0.006)$ & $(0.018)$ & $(0.040)$ & $(0.043)$ \\
\hline$\Delta \ln (\mathrm{R})_{(\mathrm{t}-1)}$ & $0.222^{* * *}$ & $-0.089^{*}$ & $-0.096^{*}$ & 0.049 \\
\hline
\end{tabular}




\begin{tabular}{|c|c|c|c|c|}
\hline & $(0.054)$ & $(0.046)$ & $(0.051)$ & $(0.054)$ \\
\hline$R^{2}-a d j$ & 0.151 & 0.111 & 0.117 & 0.101 \\
\hline$N$ & 1277 & 1015 & 1364 & 1358 \\
\hline Wooldridge & 40.805 & 162.951 & 29.059 & 66.620 \\
\hline \multicolumn{5}{|c|}{ II. Vacancy rate and space separated } \\
\hline \multirow[t]{2}{*}{$\Delta \ln (\mathrm{EA})$} & $0.618^{*}$ & $0.314 * *$ & 0.437 & $1.254^{*}$ \\
\hline & $(0.319)$ & $(0.134)$ & $(0.331)$ & $(0.650)$ \\
\hline \multirow[t]{2}{*}{$\ln (\hat{v})$} & $0.017^{*}$ & -0.003 & 0.022 & 0.009 \\
\hline & $(0.009)$ & $(0.052)$ & $(0.028)$ & $(0.010)$ \\
\hline \multirow[t]{2}{*}{$\ln (\mathrm{s})$} & $0.496 * * *$ & 0.073 & 0.031 & -0.009 \\
\hline & $(0.182)$ & $(0.314)$ & $(0.467)$ & $(0.464)$ \\
\hline \multirow[t]{2}{*}{$u_{(t-1)}$} & $-0.093 * * *$ & $-0.166 * * *$ & $-0.228 * * *$ & $-0.194 * * *$ \\
\hline & $(0.008)$ & $(0.017)$ & $(0.043)$ & $(0.034)$ \\
\hline \multirow[t]{2}{*}{$\Delta \ln (\mathrm{R})_{(\mathrm{t}-1)}$} & $0.184 * * *$ & $-0.087^{*}$ & $-0.090 *$ & 0.053 \\
\hline & $(0.049)$ & $(0.045)$ & $(0.049)$ & $(0.054)$ \\
\hline$R^{2}-a d j$ & 0.213 & 0.115 & 0.141 & 0.120 \\
\hline$N$ & 1277 & 1015 & 1364 & 1358 \\
\hline Wooldridge & 105.986 & 149.432 & 29.675 & 74.232 \\
\hline \multicolumn{5}{|c|}{ III. No vacancy rate } \\
\hline \multirow[t]{2}{*}{$\Delta \ln (\mathrm{EA})$} & $0.781 *$ & $0.350 * *$ & 0.524 & $1.394^{*}$ \\
\hline & $(0.388)$ & $(0.137)$ & $(0.386)$ & $(0.723)$ \\
\hline \multirow[t]{2}{*}{$\Delta \ln (\mathrm{s})$} & 0.336 & 0.099 & 0.161 & -0.011 \\
\hline & $(0.216)$ & $(0.311)$ & $(0.471)$ & $(0.470)$ \\
\hline \multirow[t]{2}{*}{$\mathrm{u}_{(\mathrm{t}-1)}$} & $-0.062 * * *$ & $-0.160 * * *$ & $-0.191 * * *$ & $-0.184^{* * *}$ \\
\hline & $(0.009)$ & $(0.019)$ & $(0.040)$ & $(0.037)$ \\
\hline \multirow[t]{2}{*}{$\Delta \ln (\mathrm{R})_{(\mathrm{t}-1)}$} & $0.212 * * *$ & $-0.088 *$ & $-0.099 *$ & 0.052 \\
\hline & $(0.059)$ & $(0.046)$ & $(0.052)$ & $(0.054)$ \\
\hline$R^{2}-a d j$ & 0.171 & 0.113 & 0.115 & 0.112 \\
\hline$N$ & 1277 & 1015 & 1364 & 1358 \\
\hline Wooldridge & 62.781 & 169.217 & 28.211 & 71.045 \\
\hline
\end{tabular}

This table reports the results from the error correction model of different property types' rents $(R)$ for 33 (office), 32 (retail), or 34 (industrial, flex) CBSAs, considering all quality grades (A, B and C). All models are measured including a constant term and binary variables for each metropolitan area (estimated coefficients not shown), omitting Atlanta-Sandy Springs-Marriett, GA. The dependent variable is $\ln (R)$ and $\Delta \ln (R)$ for long and short run models, respectively. $R$ stands for real rent, $E A$ is sector specific employment for office, industrial, and flex property types and retail sales for the retail property type, $v^{\wedge} v^{\wedge}$ is the fitted vacancy rate, and $s$ is the sector specific stock of space. $\mathrm{N}$ is the number of observations. Wooldridge is the Wooldridge test for autocorrelation in panel data. In all cases, the $p$-value is 0.000 , so the null hypothesis of no serial correlation is strongly rejected. Robust standard error (adjusted for clusters in CBSA) statistics appear in parenthesis. ${ }^{*} p=0.10, * * p=0.05$, $* * * p=0.01$

Panel I of Table 5 shows the result for the long run rent model. Both the short run and long run equations are pooled across all available metropolitan areas. Hausman tests reveal that fixed effects are preferred in almost all specifications. To ease comparison of the results across different subsamples, all pooled estimates are reported use fixed effects. ${ }^{\text {Footnote13 }}$ We test for the stationarity of $u_{t}$ using augmented Dickey-Fuller (ADF) tests. The lag order for the ADF tests is determined by the AIC statistics. In each case, we find at least one panel is stationary, 
suggesting the variables in the level equation are cointegrated. ${ }^{\text {Footnote14 }}$ The explanatory power of the long run model is much higher than the short run model. For example, in Table 5 panel I adjusted $R^{2} s$ range from 0.74 for flex space to 0.89 for industrial space in the long run model, but only 0.10 for flex space and 0.15 for office space in the short run model (panel I of Table 6). This stands to reason because the long-term nature of commercial leases makes rents stickier than employment or sales data.

As expected, the Wooldridge (2002) statistic, which is designed for panel data with fixed effects, indicates autocorrelation in the error term for the long run and short run models (Drukker 2003). However, we relax the assumption of independence of observations and use the Huber and White sandwich estimator (sometimes referred to as the clustered or Rogers standard errors) of variance. This approach adjusts the standard errors to reflect the fact that we have repeated observations from one location -- these repeated observations are likely to be correlated with each other and therefore provide less information than independent observations. This approach is designed to correct for the correlation of the residuals within each metropolitan area. There is evidence that two frequently used techniques to resolve this problem, Fama-MacBeth and Newey-West, have standard errors that are biased downward in a panel setting and that the Rogers or clustered standard errors are preferred (Petersen 2009). Therefore, while the Wooldridge statistics suggested a correlation problem within each metropolitan area, which would bias the standard errors, the clustering technique helps to mitigate this problem.

Economic activity, $\ln (E A)$, whether measured by sector specific employment or consumer expenditures, is always positively associated with higher rents in the long run and almost always positively associated in the short run. The precision of the results varies across property types; office space typically has the least precise results. Consistent with the prior literature, occupied space, $\ln \left[\left(1-v^{\wedge} v^{\wedge}\right) \times s\right]$, is statistically insignificant for three of the four property types in the long run model and insignificant for all four property types in the short run model.

While the results are generally consistent with the prior literature, there are substantial differences in the results across property types. For example, among the four property types, in the long run, rents for flex space are the most sensitive to changing economic activity. This may reflect the unique attributes of flex property. For example, while flex property has many of the characteristics of industrial property, rents are much higher (almost twice as high in our data). The building is typically a big box and most of the time, at least in the Costar database, the use of the property is for warehouse whether the property is identified as flex or industrial. Flex space can also include a showroom or office space, which can be used for the selling goods and services and administration activities. Since customers, whether businesses or consumers, are more likely to visit the location, it makes sense that flex property is considered to be a little nicer with a few more amenities (landscaping and more appealing exterior).

The coefficient on the lagged change in rents, $\Delta \ln (R)_{\mathrm{t}-1}$, indicates that there is substantially more persistence in short run changes in office rents than in the other property type rents. However, the lack of precision in the long run office results engenders some skepticism regarding the short run results. For retail and industrial space, increasing rents in one quarter are associated with a decrease in rents in the next quarter.

Different property types return to equilibrium at substantially different speeds. The coefficient on the error correction term, $u_{\mathrm{t}-1}$, in Table 6 panel I indicates this speed. Retail, industrial, and flex property all move back to equilibrium at approximately the same rate, 16 to 19\% per quarter, but office property returns to equilibrium at a much slower rate of just under $4 \%$ per quarter. Unfortunately, the prior literature provides little guidance on the expected speed of adjustment since it reports annual error corrections ranging from about $95 \%$ to almost zero for office property. The slower adjustment of office property seems consistent with a property type that can take a long time to build and has long lease terms. Downtown office property can take 3 to 8 years to obtain 
approvals, financing, and construction which can make it slow to respond to demand shocks and prior supply shocks. In addition, the use of concessions may slow the speed at which rents appear to move back to equilibrium. For retail, industrial, and flex property types, our results indicate that over the course of 1 year the majority of the disequilibrium is corrected. Again, this result, a faster adjustment back to equilibrium, seems reasonable because these property types are usually fairly simple structures with much of the interior design customized for the individual tenant.

Panel II in Tables 5 and 6 adjusts the specification and breaks occupied space into its two components - the vacancy rate, $v$, and total space (both occupied and unoccupied) in the market, $s$. All the specifications are estimated with fixed effects. Therefore, the results should be interpreted as within group results and each variable is effectively mean deleted at the metropolitan area. If the prior results are miss-specified, we should expect higher vacancy rates to have a negative impact on rents. The results find evidence of this in the office space market and industrial space market, but not in retail or flex space markets. Again, vacancy and the supply of space results are inconsistent and largely insignificant in the short run model.

Panel III in Tables 5 and 6 continues with a pooled approach but does not include the vacancy rate. With fixed effects, a high vacancy rate indicates that the rate is high for the area over the time period studied, not whether it is above or below an equilibrium rate or higher or lower than other areas. This limits the applicability of the vacancy coefficient. In addition, by definition, vacancy rates reflect the interaction of demand conditions (the amount of space demanded) and supply conditions (the amount of space provided). However, the spirit of this paper is to identify supply and demand through reasonable proxies. A reasonable proxy for supply is the square feet of space supplied and a reasonable proxy for demand is economic activity. These are the proxies included in panel III. The results, as compared to panel II, show a larger demand effect and an increase in precision in the long run models for all property types. In terms of supply, the coefficient for office space is negative, as expected, and significant at the $10 \%$ level. However, supply is positive and significant for retail space and insignificant for industrial and flex. The short run model shows very similar patterns of error correction, or speed of adjustment, and responses to changing economic activity and supply conditions as found earlier.

\section{De-Pooling the Long Run Model and Heterogeneity}

This section examines one possible type of the heterogeneity-location. The pooled long run results largely meet expectations that more demand is associated with higher rents in the long run and the rents do not adjust instantaneously. However, there is a lack of precision in the results. In addition, while office property has the expected persistence in rent changes, both retail and industrial rents had negative persistence. This characteristic of oscillating short run rents on a quarterly basis seems unrealistic and may just indicate random noise. There may be many reasons for this lack of precision including data quality, measurement error, location, city size, declining or increasing rents, property quality, or just too short a time period to identify the long run.

All the prior tests in this paper have estimated the long run relationships by assuming that demand and supply have the same impact in all metropolitan areas. Yet each area has its own institutional, geographical, and economic history that is likely to affect the relationship between rents and supply and demand conditions. For instance, it seems unlikely that the marginal impact of lower levels of office related employment in Detroit will be the same as in Dallas. Therefore, we estimate the long run relationship using the specification in panel III of Tables 5 and 6 separately for each metropolitan area.

This approach is cumbersome and creates a lot of long run results. Therefore, we try to summarize the results. The adjusted $R^{2} s$ are on average from $42 \%$ to $60 \%$ across the four property types with considerable variation across areas. Table 7 reports the coefficient and standard error for the effect of economic activity for each property type. ${ }^{\text {Footnote15 }}$ Again, there is considerable heterogeneity across property types and metropolitan areas. 
For example, consistent with the pooled results, for office property economic activity has a positive and statistically significant impact on rents in the long run for 17 of the areas, but for 11 areas there is a negative and statistically significant impact. For retail, industrial, and flex property the ratio of positive to negative and statistically significant impacts are 16/4, 26/3 and 18/3. Therefore, the impact of economic activity meets expectations more often in these property types.

Table 7 Results for demand (In EA), long-run model, by metropolitan area

\begin{tabular}{|c|c|c|c|c|}
\hline Metropolitan area & Office & Retail & Industrial & Flex \\
\hline \multirow[t]{2}{*}{ Atlanta } & $-0.401^{*}$ & $0.630 * * *$ & $1.962 * * *$ & 0.059 \\
\hline & $(0.217)$ & $(0.190)$ & $(0.181)$ & $(0.474)$ \\
\hline \multirow[t]{2}{*}{ Austin } & $1.457^{* *}$ & -0.074 & $0.587^{* *}$ & 1.074 \\
\hline & $(0.58)$ & $(0.152)$ & $(0.219)$ & $(0.737)$ \\
\hline \multirow[t]{2}{*}{ Baltimore } & $2.742 * * *$ & 0.217 & $0.796 * * *$ & $3.470 * * *$ \\
\hline & $(0.352)$ & $(0.159)$ & $(0.127)$ & (0.759) \\
\hline \multirow[t]{2}{*}{ Charlotte } & $0.355^{*}$ & $-1.224 * * *$ & $1.752 * * *$ & $3.906 * * *$ \\
\hline & $(0.189)$ & $(0.414)$ & $(0.178)$ & $(0.396)$ \\
\hline \multirow[t]{2}{*}{ Chicago } & $-1.070 * * *$ & $-0.889 * * *$ & $0.859 * * *$ & $5.904 * * *$ \\
\hline & $(0.270)$ & $(0.271)$ & $(0.158)$ & $(0.846)$ \\
\hline \multirow[t]{2}{*}{ Cincinnati } & 0.882* & 0.896* & $1.141^{* * *}$ & -3.036 \\
\hline & $(0.472)$ & $(0.455)$ & $(0.173)$ & $(2.262)$ \\
\hline \multirow[t]{2}{*}{ Cleveland } & $-4.603 * * *$ & $0.561 * *$ & $0.481 * * *$ & 1.888 \\
\hline & $(0.817)$ & $(0.205)$ & $(0.047)$ & $(2.233)$ \\
\hline \multirow[t]{2}{*}{ Columbus } & $-2.323 * * *$ & -0.445 & $1.044^{* * *}$ & 1.024 \\
\hline & $(0.216)$ & $(0.302)$ & $(0.170)$ & $(0.647)$ \\
\hline \multirow[t]{2}{*}{ Dallas } & $1.510 * * *$ & $-1.417^{* * *}$ & $0.716^{* * *}$ & 0.484 \\
\hline & $(0.158)$ & $(0.345)$ & $(0.208)$ & $(0.564)$ \\
\hline \multirow[t]{2}{*}{ Denver } & - & - & 0.227 & $1.606^{* * *}$ \\
\hline & & & $(0.282)$ & $(0.310)$ \\
\hline \multirow[t]{2}{*}{ Detroit } & $0.500 * * *$ & $2.161^{* * *}$ & $0.603 * * *$ & $2.530 * * *$ \\
\hline & $(0.156)$ & $(0.298)$ & $(0.125)$ & $(0.461)$ \\
\hline \multirow[t]{2}{*}{ Houston } & $1.675^{* * *}$ & $1.023^{* * *}$ & $1.344^{* * *}$ & $-4.576 * * *$ \\
\hline & $(0.432)$ & $(0.243)$ & $(0.444)$ & $(0.482)$ \\
\hline \multirow[t]{2}{*}{ Indianapolis } & -0.541 & 0.074 & $1.206 *$ & -2.810 \\
\hline & $(0.515)$ & $(0.176)$ & $(0.647)$ & (2.128) \\
\hline \multirow[t]{2}{*}{ Jacksonville } & -0.220 & $3.274 * * *$ & $1.458 * * *$ & 0.397 \\
\hline & $(0.204)$ & $(0.78)$ & $(0.216)$ & $(1.236)$ \\
\hline \multirow[t]{2}{*}{ Kansas City } & $0.734 * * *$ & $0.265^{* *}$ & 0.611 & $1.390 * * *$ \\
\hline & $(0.234)$ & $(0.129)$ & $(0.657)$ & $(0.437)$ \\
\hline \multirow[t]{2}{*}{ Los Angeles } & $2.248 * * *$ & $0.805^{* * *}$ & $0.536 * * *$ & $1.549 * *$ \\
\hline & $(0.296)$ & $(0.113)$ & $(0.134)$ & $(0.622)$ \\
\hline \multirow[t]{2}{*}{ Memphis } & $-1.062 * * *$ & -0.529 & 0.795 & $-7.364 * * *$ \\
\hline & $(0.232)$ & $(0.432)$ & $(0.483)$ & $(1.806)$ \\
\hline \multirow[t]{2}{*}{ Miami } & $-0.651 * *$ & $0.647^{* * *}$ & $0.795^{* * *}$ & -0.316 \\
\hline & $(0.259)$ & $(0.121)$ & $(0.176)$ & $(0.863)$ \\
\hline Nashville & $-1.628 * * *$ & $-1.166^{* * *}$ & $0.634^{*}$ & -0.821 \\
\hline
\end{tabular}




\begin{tabular}{|c|c|c|c|c|}
\hline & $(0.368)$ & $(0.279)$ & $(0.353)$ & $(1.058)$ \\
\hline \multirow[t]{2}{*}{ New York } & $2.869 * * *$ & - & $1.522 * * *$ & 1.228 \\
\hline & $(0.371)$ & & $(0.177)$ & (1.971) \\
\hline \multirow[t]{2}{*}{ Orlando } & -0.069 & 0.062 & $1.129 * * *$ & $4.033 * * *$ \\
\hline & $(0.248)$ & $(0.282)$ & $(0.224)$ & $(0.497)$ \\
\hline \multirow[t]{2}{*}{ Philadelphia } & 0.831 & $0.546 * *$ & $0.262^{*}$ & $-9.846 * * *$ \\
\hline & $(0.930)$ & $(0.235)$ & $(0.142)$ & $(1.754)$ \\
\hline \multirow[t]{2}{*}{ Phoenix } & $0.987 * * *$ & $1.357 * * *$ & 0.053 & $1.365^{* * *}$ \\
\hline & $(0.311)$ & $(0.286)$ & $(0.293)$ & $(0.332)$ \\
\hline \multirow[t]{2}{*}{ Pittsburgh } & $-1.020 * * *$ & -0.169 & $-0.516 * * *$ & $2.253 * *$ \\
\hline & $(0.354)$ & $(0.205)$ & $(0.147)$ & $(1.03)$ \\
\hline \multirow[t]{2}{*}{ Portland } & -0.425 & 0.069 & $-0.444^{* *}$ & -0.805 \\
\hline & $(0.328)$ & $(0.137)$ & (0.197) & $(0.705)$ \\
\hline \multirow[t]{2}{*}{ Raleigh } & $-0.772 * *$ & 0.266 & $1.030 * * *$ & $0.668^{*}$ \\
\hline & $(0.306)$ & $(0.455)$ & $(0.142)$ & $(0.371)$ \\
\hline \multirow[t]{2}{*}{ Riverside } & $0.947 * * *$ & $0.728 * *$ & $0.682 * * *$ & $1.358 * * *$ \\
\hline & $(0.122)$ & $(0.285)$ & $(0.203)$ & $(0.461)$ \\
\hline \multirow[t]{2}{*}{ Sacramento } & $1.186 * * *$ & $1.537^{* * *}$ & $0.659 *$ & $5.479 * * *$ \\
\hline & $(0.331)$ & $(0.305)$ & $(0.363)$ & $(1.188)$ \\
\hline \multirow[t]{2}{*}{ St. Louis } & $1.034^{* * *}$ & $0.511^{* *}$ & $2.498 * * *$ & -2.225 \\
\hline & $(0.308)$ & $(0.199)$ & $(0.428)$ & $(2.031)$ \\
\hline \multirow[t]{2}{*}{ San Diego } & $3.177^{* * *}$ & $0.336^{*}$ & $0.340 * * *$ & $5.808 * * *$ \\
\hline & $(0.565)$ & $(0.198)$ & $(0.106)$ & (1.935) \\
\hline \multirow[t]{2}{*}{ San Jose } & $3.783 * * *$ & -0.751 & $2.011^{* * *}$ & $5.383 * * *$ \\
\hline & $(0.432)$ & $(0.480)$ & $(0.175)$ & $(0.241)$ \\
\hline \multirow[t]{2}{*}{ Seattle } & $1.592 * * *$ & $1.642 * * *$ & 0.056 & $3.110 * * *$ \\
\hline & $(0.535)$ & $(0.197)$ & $(0.106)$ & $(0.377)$ \\
\hline \multirow[t]{2}{*}{ Tampa } & $-0.725^{* *}$ & -0.749 & $1.419 * * *$ & $0.767 * * *$ \\
\hline & $(0.312)$ & $(0.524)$ & $(0.296)$ & $(0.211)$ \\
\hline \multirow[t]{2}{*}{ Washington } & $3.035^{* * *}$ & $2.798 * * *$ & $-0.243^{* *}$ & $2.505^{* * *}$ \\
\hline & $(0.167)$ & $(0.372)$ & $(0.119)$ & $(0.289)$ \\
\hline
\end{tabular}

This specification is estimated separately for each metropolitan area. This specification includes $E A$ (a sector specific employment for office, industrial, and flex property types and retail sales for the retail property type), $s$ (a sector specific stock of space office, industrial, and flex property types) and a constant as explanatory variables for each metropolitan area and property type. Standard errors statistics appear in parenthesis.

${ }^{*} p=0.10,{ }^{* *} p=0.05, * * * p=0.01$

We should expect that in locations where it is difficult to build, demand effects on rents may be different than in places where it is easier to build. Saiz (2010) reports the fraction of land in the metropolitan area that is not available for development and finds that it is an important part of housing supply elasticity. Saiz (2010) also reports the Wharton Regulatory Index which reflects regulatory constraints on building housing. ${ }^{\text {Footnote } 16}$ The correlation between the estimated coefficient for $\operatorname{In} E A$ in the long run results and the fraction of land that is unavailable or the regulatory index is, respectively, for office property 0.15 and 0.21 , for retail property 0.13 and 0.16 , for industrial property -0.08 and -0.36 , and for flex property 0.43 and -0.02 . Therefore, in the long run, for office, retail, and flex property types, locations with less available land have larger increases in rents in response 
to more demand. The results for the regulatory index are more mixed and likely reflect measurement error in the index for commercial property.

In Table 8 the coefficient for the impact of space is reported. For example, for office space the supply of space has a negative and statistically significant impact on rents in the long run for 22 of the areas, but for 3 areas there is a positive and statistically significant impact. For at least office space, the de-pooled long run results are more consistent and meet expectations for supply. Unfortunately, the opposite is true for retail, industrial, and flex property. For retail, industrial, and flex property the ratios of negative to positive impacts are 4/24, 5/19, $12 / 7$.

Table 8 Results for supply (In s), long-run model, by metropolitan area

\begin{tabular}{|c|c|c|c|c|}
\hline Metropolitan area & Office & Retail & Industrial & Flex \\
\hline \multirow[t]{2}{*}{ Atlanta } & 0.076 & $0.561 * * *$ & $0.233^{* * *}$ & 0.800 \\
\hline & $(0.233)$ & $(0.115)$ & $(0.063)$ & $(0.594)$ \\
\hline \multirow[t]{2}{*}{ Austin } & -1.056 & $0.709 * * *$ & -0.668 & 0.386 \\
\hline & $(0.983)$ & (0.096) & $(0.504)$ & $(1.157)$ \\
\hline \multirow[t]{2}{*}{ Baltimore } & $-1.645 * * *$ & $4.198 * * *$ & $1.838^{* * *}$ & $-1.610 * * *$ \\
\hline & $(0.195)$ & $(0.314)$ & $(0.341)$ & $(0.523)$ \\
\hline \multirow[t]{2}{*}{ Charlotte } & $-1.330 * * *$ & $1.567^{* * *}$ & $6.305^{* * *}$ & $-3.770 * * *$ \\
\hline & $(0.270)$ & $(0.248)$ & $(0.739)$ & $(0.452)$ \\
\hline \multirow[t]{2}{*}{ Chicago } & $-1.750 * * *$ & $-1.047 * * *$ & $1.144^{* *}$ & $1.041 * * *$ \\
\hline & $(0.265)$ & $(0.269)$ & $(0.433)$ & $(0.212)$ \\
\hline \multirow[t]{2}{*}{ Cincinnati } & $-3.425 * * *$ & $2.838 * * *$ & $1.696 * * *$ & 0.690 \\
\hline & $(0.458)$ & $(0.515)$ & $(0.569)$ & $(0.454)$ \\
\hline \multirow[t]{2}{*}{ Cleveland } & $-4.134 * * *$ & $1.382 * * *$ & $-6.684 * * *$ & -0.939 \\
\hline & $(0.498)$ & $(0.212)$ & $(1.140)$ & $(1.510)$ \\
\hline \multirow[t]{2}{*}{ Columbus } & $-0.770 * * *$ & $0.948^{*}$ & 0.660 & $-1.006 * * *$ \\
\hline & $(0.191)$ & $(0.511)$ & $(0.568)$ & $(0.311)$ \\
\hline \multirow[t]{2}{*}{ Dallas } & $-3.718^{* * *}$ & $-1.992 * * *$ & -0.076 & $-2.458 * * *$ \\
\hline & $(0.206)$ & $(0.362)$ & $(0.230)$ & $(0.648)$ \\
\hline \multirow[t]{2}{*}{ Denver } & - & - & $-2.004 * *$ & $-1.726 * * *$ \\
\hline & & & $(0.746)$ & $(0.205)$ \\
\hline \multirow[t]{2}{*}{ Detroit } & $-3.040 * * *$ & $3.297^{* * *}$ & -2.023 & 0.201 \\
\hline & $(0.173)$ & $(0.541)$ & (1.264) & $(0.549)$ \\
\hline \multirow[t]{2}{*}{ Houston } & $-2.420 * * *$ & $1.508^{* * *}$ & $-2.131 * *$ & $5.363 * * *$ \\
\hline & $(0.681)$ & $(0.247)$ & $(0.804)$ & $(0.420)$ \\
\hline \multirow[t]{2}{*}{ Indianapolis } & -1.126 & 0.141 & -0.112 & 2.444 \\
\hline & $(0.838)$ & $(0.154)$ & $(0.782)$ & $(2.053)$ \\
\hline \multirow[t]{2}{*}{ Jacksonville } & $-0.488 * * *$ & $6.268 * * *$ & $2.703 * * *$ & -0.019 \\
\hline & $(0.135)$ & $(0.841)$ & $(0.350)$ & $(0.949)$ \\
\hline \multirow[t]{2}{*}{ Kansas City } & $-3.237 * * *$ & $1.303 * * *$ & -0.298 & $-1.248 * * *$ \\
\hline & $(0.258)$ & $(0.251)$ & $(1.586)$ & $(0.191)$ \\
\hline \multirow[t]{2}{*}{ Los Angeles } & $-2.035 * * *$ & $5.103 * * *$ & $2.942 * * *$ & $0.783^{* *}$ \\
\hline & $(0.491)$ & $(0.293)$ & $(0.475)$ & $(0.336)$ \\
\hline \multirow[t]{2}{*}{ Memphis } & -0.374 & $-0.719 * * *$ & $-1.109 * * *$ & $3.451^{* * *}$ \\
\hline & $(0.281)$ & $(0.228)$ & $(0.242)$ & \begin{tabular}{|l|}
$(1.033)$ \\
\end{tabular} \\
\hline
\end{tabular}




\begin{tabular}{|c|c|c|c|c|}
\hline \multirow[t]{2}{*}{ Miami } & $1.140 * * *$ & $2.051 * * *$ & $2.836 * * *$ & -0.796 \\
\hline & $(0.303)$ & $(0.278)$ & $(0.625)$ & $(0.635)$ \\
\hline \multirow{2}{*}{ Nashville } & $1.523^{* * *}$ & $-0.410^{*}$ & $2.438 * * *$ & -1.917 \\
\hline & $(0.456)$ & $(0.207)$ & $(0.835)$ & (1.235) \\
\hline \multirow[t]{2}{*}{ New York } & $-9.398 * * *$ & - & $17.370 * * *$ & 0.394 \\
\hline & $(1.064)$ & & $(1.848)$ & $(1.557)$ \\
\hline \multirow{2}{*}{ Orlando } & -0.322 & $1.536 * * *$ & $1.261^{* * *}$ & $-3.972 * * *$ \\
\hline & $(0.281)$ & $(0.199)$ & $(0.156)$ & $(0.583)$ \\
\hline \multirow[t]{2}{*}{ Philadelphia } & $-2.114^{* *}$ & $3.039 * * *$ & 1.948 & $4.516 * * *$ \\
\hline & $(0.953)$ & $(0.550)$ & $(1.173)$ & $(0.891)$ \\
\hline \multirow[t]{2}{*}{ Phoenix } & $-0.694 * * *$ & $0.961 * * *$ & 0.022 & $-0.567 * * *$ \\
\hline & $(0.232)$ & $(0.137)$ & $(0.227)$ & $(0.200)$ \\
\hline \multirow[t]{2}{*}{ Pittsburgh } & $-2.307 * * *$ & 0.489 & $-4.451 * * *$ & $3.290 * * *$ \\
\hline & $(0.382)$ & $(0.348)$ & $(1.361)$ & $(0.654)$ \\
\hline \multirow[t]{2}{*}{ Portland } & 1.237 & $1.259 * * *$ & $1.705^{* * *}$ & 2.887 \\
\hline & $(0.902)$ & $(0.220)$ & $(0.283)$ & $(1.881)$ \\
\hline \multirow[t]{2}{*}{ Raleigh } & $0.759 * *$ & $0.879 * * *$ & $0.622 *$ & $-1.780 * *$ \\
\hline & $(0.342)$ & $(0.290)$ & $(0.331)$ & $(0.680)$ \\
\hline \multirow[t]{2}{*}{ Riverside } & 0.059 & $1.315^{* * *}$ & -0.078 & 0.537 \\
\hline & $(0.126)$ & $(0.143)$ & $(0.086)$ & $(0.397)$ \\
\hline \multirow[t]{2}{*}{ Sacramento } & $-0.526 * *$ & $1.584^{* * *}$ & $2.749 * * *$ & $-3.120 * * *$ \\
\hline & $(0.228)$ & $(0.215)$ & (0.674) & $(0.853)$ \\
\hline \multirow[t]{2}{*}{ St. Louis } & $-4.270 * * *$ & 0.145 & $5.038 * * *$ & 0.285 \\
\hline & $(0.385)$ & $(0.138)$ & $(1.165)$ & $(0.375)$ \\
\hline \multirow[t]{2}{*}{ San Diego } & $-1.349 * * *$ & $3.120 * * *$ & $1.325^{* * *}$ & -1.554 \\
\hline & $(0.325)$ & $(0.767)$ & $(0.252)$ & $(1.192)$ \\
\hline \multirow[t]{2}{*}{ San Jose } & $-2.742 * * *$ & $-5.762 * * *$ & $20.742 * * *$ & $1.230 * *$ \\
\hline & $(0.373)$ & $(1.002)$ & (3.997) & $(0.502)$ \\
\hline \multirow[t]{2}{*}{ Seattle } & -1.582 & $3.068^{* * *}$ & -0.063 & $-1.618 *$ \\
\hline & $(1.108)$ & $(0.181)$ & $(0.184)$ & $(0.856)$ \\
\hline \multirow[t]{2}{*}{ Tampa } & $0.641 * *$ & $1.938 * * *$ & $3.499 * * *$ & 0.228 \\
\hline & $(0.284)$ & $(0.384)$ & $(0.778)$ & $(0.338)$ \\
\hline \multirow[t]{2}{*}{ Washington } & $-2.815^{* * *}$ & $4.025 * * *$ & $0.775^{* * *}$ & $-1.290 * * *$ \\
\hline & $(0.180)$ & $(0.419)$ & $(0.114)$ & $(0.267)$ \\
\hline
\end{tabular}

This specification is estimated separately for each metropolitan area. This specification includes $E A$ (a sector specific employment for office, industrial, and flex property types and retail sales for the retail property type), $s$ (a sector specific stock of space office, industrial, and flex property types) and a constant as explanatory variables for each metropolitan area and property type. Standard errors statistics appear in parenthesis.

${ }^{*} p=0.10, * * p=0.05, * * * p=0.01$

\section{Space Quality}

Another potential explanation for the heterogeneity of the long run results could lie in quality segments of the property that the data covers. In fact, the prior literature has focused on top quality property. There are some reasons to expect that property markets may be segmented in terms of demand and supply across quality spectrums. Consider the office market. Demand for the best office building will be derived from lawyers, accountants, financial analysts, consultants, and other high value added professionals who sell their intellectual 
capital. These types of spaces and buildings tend to be concentrated in downtown areas. Demand for lower quality space and buildings will be derived from back office activity such as processing, payroll, and more routinized activity with a lower value added component. These types of spaces tend to be dispersed in more suburban locations. Therefore, demand for space is highly segmented. In addition, the supply of space is also segmented by location and it is expensive to upgrade a low quality space into a high quality space.

The quality of each property is proxied by grades assigned by the brokers and confirmed by Costar. Therefore, they represent the market's distinction of overall quality, which will reflect many different inputs. For example, a grade $A$ office building will likely be multiple stories with a staffed lobby, concierge service, underground parking, and retail on the first floor. A grade B building could be in an office park and well maintained, but with many fewer amenities.

The long run model is rerun for each property grade and each metropolitan area. In general, the results are improved. For example, for class A office property statistically significant positive coefficients are found for economic activity in 12 metropolitan areas and statistically significant negative coefficients in 9 metropolitan areas. For industrial and flex property the ratios of statistically significant positive to negative impacts are 13/6 and 16/7. ${ }^{\text {Footnote17 }}$ These do not show much improvement over the results using all property grades. The results for supply do improve. The ratios of statistically negative coefficients to positive coefficients for office, industrial and flex are $22 / 2,13 / 6$, and $12 / 7$. ${ }^{\text {Fotnote } 18}$ While the precision is still low, the ratios do indicate that for the majority of the locations the expected impact of supply is found. ${ }^{\text {Footnote19 }}$

\section{Speed of Adjustment: Metropolitan Area Specific Error}

Using the metropolitan area specific results from Tables 7 and 8, the errors are calculated and used to estimate the error correction process. The results are reported in Table 9. Similar to the prior estimates, economic activity has a positive impact on rents in the short run and the coefficients are marginally significant. Supply is also insignificant. However, the error correction is much faster relative to the pooled error results. For example, for office property, the speed of adjustment increases from $6 \%$ to $17 \%$. There are similar increases in the speed of adjustment estimates for retail, industrial, and flex properties so that in two or three quarters rents have returned back to equilibrium. The fastest adjustment is found for industrial properties. The extent of persistence is also either positive and significant or insignificant. Again, the level of persistence is highest for office property but there is also some persistence for flex property. This result is more consistent with priors that rents for commercial property are fairly smooth and should not oscillate around equilibrium on a quarterly basis. ${ }^{\text {Footnote20 }}$

Table 9 Speed of adjustment-metropolitan area specific error $\mathbf{u}_{(\mathrm{t}-1)}$

\begin{tabular}{|l|l|l|l|l|}
\hline & Office & Retail & Industrial & Flex \\
\hline Short run model & & & & \\
\hline Constant & $-0.009 * * *$ & $0.004^{*}$ & 0.000 & 0.002 \\
\hline & $(0.002)$ & $(0.002)$ & $(0.002)$ & $(0.004)$ \\
\hline$\Delta \ln (\mathrm{EA})$ & $0.410^{*}$ & $0.390^{*}$ & 0.547 & 0.676 \\
\hline & $(0.211)$ & $(0.194)$ & $(0.390)$ & $(0.689)$ \\
\hline$\Delta \ln (\mathrm{s})$ & 0.337 & 0.033 & -0.225 & -0.137 \\
\hline & $(0.241)$ & $(0.316)$ & $(0.334)$ & $(0.381)$ \\
\hline $\mathrm{u}_{(\mathrm{t}-1)}$ & $-0.170^{* * *}$ & $-0.278^{* * *}$ & $-0.478^{* * *}$ & $-0.352^{* * *}$ \\
\hline & $(0.038)$ & $(0.039)$ & $(0.047)$ & $(0.035)$ \\
\hline$\Delta \ln (\mathrm{R})_{(\mathrm{t}-1)}$ & $0.225^{* * *}$ & -0.006 & 0.024 & $0.122 * *$ \\
\hline & $(0.035)$ & $(0.049)$ & $(0.049)$ & $(0.052)$ \\
\hline$R^{2}-a d j$ & 0.227 & 0.125 & 0.240 & 0.188 \\
\hline
\end{tabular}




\begin{tabular}{|l|l|l|l|l|}
\hline$N$ & 1277 & 1015 & 1364 & 1358 \\
\hline Wooldridge & 200.234 & 213.992 & 37.696 & 62.993 \\
\hline
\end{tabular}

The long run model results are reported in Tables 7 and 8 . All models are measured including a constant term and binary variables for each metropolitan area (estimated coefficients not shown), omitting Atlanta-Sandy Springs-Marriett, GA. The dependent variable is $\Delta \ln (R)$. $R$ stands for real rent, $E A$ is sector specific employment for office, industrial, and flex property types and retail sales for the retail property type and $s$ is the sector specific stock of space. $\mathrm{N}$ is the number of observations. Wooldridge is the Wooldridge test for autocorrelation in panel data. In all cases, the $p$-value is 0.000 , so the null hypothesis of no serial correlation is strongly rejected. Robust standard error (adjusted for clusters in CBSA) statistics appear in parenthesis. ${ }^{*} p=0.10,{ }^{*} p=0.05$, $* * * p=0.01$

Table 10 examines the speed of adjustment by property quality or grade. Across all property types the speed, $u_{\mathrm{t}}$ ${ }_{1}$, of adjustment back to equilibrium tends to be higher within a quality grade than across all quality grades, especially for grade A properties. For example, for grade A office space the adjustment back to equilibrium is $70.5 \%$ while for all office space it was $17 \%$. For grade A industrial space, the speed of adjustment is 59.3 and, for all grades together, it is $47.8 \%$. Since rents move very quickly back to equilibrium within grade, this set of results is consistent with market segmentation. All the quality controlled results also show modest levels of persistence that is statistically significant for 7 of the 8 estimates. These results (more persistence and faster speed of adjustment) and the fact that average asking rents are more constant quality when building grade is controlled for, makes these set of results our preferred results.

Table 10 Results for speed of adjustment by quality grade

\begin{tabular}{|l|l|l|l|}
\hline & Grade A & Grade B & Grade C \\
\hline I. Office & & & \\
\hline$\Delta \ln (\mathrm{EA})$ & $-1.306^{* *}$ & -0.344 & 0.481 \\
\hline & $(0.506)$ & $(0.445)$ & $(0.768)$ \\
\hline$\Delta \ln (\mathrm{s})$ & 0.108 & 0.048 & 0.694 \\
\hline & $(0.343)$ & $(0.915)$ & $(1.049)$ \\
\hline $\mathrm{U}_{(\mathrm{t}-1)}$ & $-0.705^{* * *}$ & $-0.589^{* * *}$ & $-0.427^{* *}$ \\
\hline & $(0.191)$ & $(0.190)$ & $(0.193)$ \\
\hline$\Delta \ln (\mathrm{R})(\mathrm{t}-1)$ & $0.090^{* * *}$ & $0.111^{* * *}$ & $0.101^{* * *}$ \\
\hline & $(0.012)$ & $(0.008)$ & $(0.013)$ \\
\hline$R^{2}$-adj & 0.611 & 0.525 & 0.310 \\
\hline$N$ & 1373 & 1383 & 1386 \\
\hline Wooldridge & 142.513 & 666.012 & 504.359 \\
\hline $\mathrm{II} . \operatorname{Industrial}$ & & & \\
\hline$\Delta \ln (\mathrm{EA})$ & -0.504 & 0.494 & 0.233 \\
\hline & $(0.614)$ & $(0.294)$ & $(0.303)$ \\
\hline$\Delta \ln (\mathrm{s})$ & -0.177 & 0.430 & 0.235 \\
\hline & $(0.121)$ & $(0.279)$ & $(0.959)$ \\
\hline $\mathrm{U}_{(\mathrm{t}-1)}$ & $-0.593^{* * *}$ & $-0.546^{* * *}$ & $-0.419^{* * *}$ \\
\hline & $(0.102)$ & $(0.059)$ & $(0.037)$ \\
\hline$\Delta \operatorname{In}(\mathrm{R})$ (t-1) & $0.126^{*}$ & 0.000 & $0.134^{* * *}$ \\
\hline & $(0.074)$ & $(0.052)$ & $(0.047)$ \\
\hline$R^{2}$-adj & 0.265 & 0.525 & 0.203 \\
\hline & & & \\
\hline
\end{tabular}




\begin{tabular}{|l|l|l|l|}
\hline$N$ & 1100 & 1379 & 1375 \\
\hline Wooldridge & 46.788 & 25.877 & 67.001 \\
\hline III. Flex & & & \\
\hline$\Delta \ln (\mathrm{EA})$ & & 0.735 & 0.275 \\
\hline & & $(0.515)$ & $(0.947)$ \\
\hline$\Delta \ln (\mathrm{s})$ & & 0.029 & 1.201 \\
\hline & & $(0.263)$ & $(1.345)$ \\
\hline $\mathrm{u}_{(\mathrm{t}-1)}$ & & $-0.345^{* * *}$ & $-0.426^{* * *}$ \\
\hline & & $(0.028)$ & $(0.04)$ \\
\hline$\Delta \ln (\mathrm{R})(\mathrm{t}-1)$ & & $0.165^{* * *}$ & $0.132^{* *}$ \\
\hline & & $(0.032)$ & $(0.054)$ \\
\hline$R^{2}$-adj & & 0.185 & 0.230 \\
\hline$N$ & & 1377 & 1364 \\
\hline Wooldridge & & 250.112 & 29.480 \\
\hline
\end{tabular}

The long run results are not reported (to save some space) but are available on request from the authors. The dependent variable is $\Delta \ln (R)$. All models are measured include metropolitan area fixed effects (estimated coefficients not shown). $R$ stands for real rent, $E A$ is sector specific employment for office, industrial, and flex property types and retail sales for the retail property type, and $s$ is the sector specific stock of space. $u(t-1)$ is the lagged positive residual from the long run results for each metropolitan area. $\mathrm{N}$ is the number of quarterly observations. Wooldridge is the Wooldridge test for autocorrelation in panel data. In all cases, the p-value is 0.0000 , so the null hypothesis of no serial correlation is strongly rejected. Robust standard error (adjusted for clusters in CBSA) statistics appear in parenthesis. ${ }^{*} p=0.10,{ }^{* *} p=0.05, * * * p=0.01$

\section{Various Specification Tests}

The London Effect Hendershott et al. (2002b) coined the term "the London effect" to express a belief that large cities may react differently to demand and supply shocks. To test for this effect we identify the five largest metropolitan areas in our sample: New York, Los Angeles, Chicago, Dallas, and Philadelphia. We refer to these locations as the Big 5 Metros, B5M. Our de-pooled long run results are consistent with office property results of Brounen and Jennen (2009b) and Hendershott, MacGregor, and White (2002b) - the effect of economic activity and supply is larger for very large cities. A simple correlation between city rank and the coefficient was of the anticipated direction (negative for $E A$ and positive for $s$ ) and over 0.35 in absolute value in both instances. However, these relationships were not found for other property types.

In the short run model B5M is interacted with economic activity and space. Therefore, the coefficients are additive for the largest areas. The results, as set forth in panel I of Table 11, show that in the short run large metropolitan area rents do not act very differently than in small and medium sized metropolitan areas. There are two exceptions: one, there is evidence of a slower speed of adjustment and a stronger demand effect for office property; two, we found a stronger supply effect for retail property.

Table 11 Summary of speed of adjustment specification tests

\begin{tabular}{|l|l|l|l|l|}
\hline & Office & Retail & Industrial & Flex \\
\hline I. The Five Largest Metropolitan Areas & & & & \\
\hline $\mathrm{u}_{(\mathrm{t}-1)}$ & $-0.180^{* * *}$ & $-0.292^{* * *}$ & $-0.486^{* * *}$ & $-0.351^{* * *}$ \\
\hline $\mathrm{B} 5 \mathrm{M}^{*} \Delta \ln (\mathrm{EA})$ & $(0.041)$ & $(0.039)$ & $(0.049)$ & $(0.023)$ \\
\hline & $1.265^{*}$ & -0.796 & -0.166 & -1.112 \\
\hline $\mathrm{B} 5 \mathrm{M}^{*} \Delta \ln (\mathrm{s})$ & $(0.651)$ & $(0.494)$ & $(0.258)$ & $(1.393)$ \\
\hline
\end{tabular}




\begin{tabular}{|c|c|c|c|c|}
\hline & $(0.456)$ & (0.591) & $(0.445)$ & (2.331) \\
\hline \multirow{2}{*}{$\mathrm{B} \mathrm{M}^{*} \mathrm{u}_{(\mathrm{t}-1)}$} & $0.094^{* *}$ & 0.046 & 0.105 & -0.006 \\
\hline & $(0.045)$ & $(0.102)$ & $(0.070)$ & $(0.087)$ \\
\hline \multirow[t]{2}{*}{$\mathrm{B} \mathrm{M}{ }^{*} \Delta \ln (\mathrm{R})_{(\mathrm{t}-1)}$} & -0.052 & 0.126 & 0.050 & -0.126 \\
\hline & (0.051) & $(0.080)$ & $(0.088)$ & (0.144) \\
\hline \multicolumn{5}{|c|}{ II. Positive Disequilibrium } \\
\hline \multirow[t]{2}{*}{$\mathrm{u}_{(\mathrm{t}-1)}$} & $-0.132 * * *$ & $-0.384 * * *$ & $-0.305 * * *$ & $-0.350 * * *$ \\
\hline & $(0.029)$ & $(0.087)$ & $(0.074)$ & (0.045) \\
\hline \multirow[t]{2}{*}[(u_{t-1}>0)*u_{t-1}]{} & $-0.075^{*}$ & 0.204 & $-0.300 * * *$ & -0.003 \\
\hline & $(0.039)$ & $(0.182)$ & $(0.087)$ & $(0.074)$ \\
\hline \multicolumn{5}{|c|}{ III. Positive Disequilibrium with Interactions } \\
\hline \multirow[t]{2}{*}{$\mathrm{u}_{(\mathrm{t}-1)}$} & $-0.189 * * *$ & $-0.299 * * *$ & $-0.530 * * *$ & $0.135^{* *}$ \\
\hline & (0.039) & (0.049) & $(0.061)$ & $(0.056)$ \\
\hline \multirow[t]{2}{*}[(\mathrm{u}_{\mathrm{t}-1}>0)*\Delta\operatorname{ln}(\mathrm{EA})_{\mathrm{t}}]{} & 0.599 & -0.335 & $-0.425^{* *}$ & -0.649 \\
\hline & $(0.397)$ & (0.309) & $(0.204)$ & $(0.564)$ \\
\hline \multirow[t]{2}{*}[(\mathrm{u}_{\mathrm{t}-1}>0)*\Delta\operatorname{ln}(\mathrm{s})_{\mathrm{t}}]{} & 0.018 & 1.252 & $1.732 * *$ & -0.003 \\
\hline & $(0.376)$ & $(0.803)$ & $(0.838)$ & $(0.004)$ \\
\hline \multicolumn{5}{|l|}{ IV. Large Disequilibrium } \\
\hline \multirow[t]{2}{*}{$\mathrm{u}_{(\mathrm{t}-1)}$} & $-0.171 * * *$ & $-0.197 * * *$ & $-0.234 * * *$ & $-0.237 * * *$ \\
\hline & $(0.033)$ & $(0.066)$ & $(0.043)$ & $(0.031)$ \\
\hline \multirow[t]{2}{*}[(\mathrm{Big}\mathrm{u}_{\mathrm{t}-1})*\mathrm{u}_{\mathrm{t}-1}]{} & 0.001 & -0.099 & $-0.312 * * *$ & $-0.142 * * *$ \\
\hline & $(0.059)$ & $(0.068)$ & $(0.061)$ & (0.049) \\
\hline \multicolumn{5}{|c|}{ V. Large Disequilibrium with Interactions } \\
\hline \multirow[t]{2}{*}{$\mathrm{u}_{(\mathrm{t}-1)}$} & $-0.183 * * *$ & $-0.252 * * *$ & $-0.413 * * *$ & $-0.307 * * *$ \\
\hline & $(0.020)$ & $(0.041)$ & $(0.04)$ & $(0.041)$ \\
\hline \multirow[t]{2}{*}[(\mathrm{Big}\mathrm{u})_{(\mathrm{t}-1)}*\Delta\operatorname{ln}(\mathrm{EA})_{\mathrm{t}}]{} & $6.404^{*}$ & $-5.87^{* * *}$ & 1.923 & -1.522 \\
\hline & (3.246) & $(1.715)$ & $(2.664)$ & $(4.814)$ \\
\hline \multirow[t]{2}{*}[(\mathrm{Big}\mathrm{u})_{(\mathrm{t}-1)}*\Delta\operatorname{ln}(\mathrm{s})_{\mathrm{t}}]{} & -2.727 & -1.275 & $-16.977^{*}$ & $-11.281 * *$ \\
\hline & $(2.783)$ & $(4.732)$ & $(8.695)$ & $(5.114)$ \\
\hline
\end{tabular}

This table summarized key results for different specification test of the short run model. In each case the same long run model results are used as reported in Tables 7 and 8 . The dependent variable is $\ln (R)$ and $\Delta \ln (R)$ for long and short run models, respectively, where $R$ stands for real rent. Although not reported to save space, each short run specification includes $\triangle \ln E A$, sector specific economic activity and $\Delta \ln s$, sector specific stock of space,

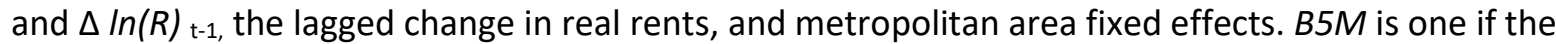
metropolitan area is one of the top five in terms of 2000 population (i.e., NY-Northern New Jersey-Long Island, LA-Long Beach-Santa Ana, Chicago-Naperville-Joliet, Dallas, or Philadelphia), and zero otherwise. $u_{(t-1)}>0$ is the lagged positive residual, which is equal to one if the lagged residual (error correction term) is positive, and is equal to zero otherwise. Big( $u$ ) is an indicator of a big error, which equals one if the residual deviates from the mean by one or more standard deviations, and zero otherwise. Robust standard error (adjusted for clusters in CBSA) statistics appear in parenthesis. ${ }^{*} p=0.10,{ }^{* *} p=0.05,{ }^{* * *} p=0.01$

\section{Speed of Adjustment: The Direction and Size of the Disequilibrium}

There may also be heterogeneity in how a metropolitan area moves back to equilibrium. Panels II and III of Table 11 ask, if rents are too high relative to the equilibrium level, do they move back to equilibrium faster or slower? Panel IV asks, if rents are a long distance from equilibrium (a big disequilibrium), does the market adjust 
more quickly or slowly than in typical periods of disequilibrium? The long run results are not reported because they are identical to those in Tables 7 and 8 as discussed in the section De-Pooling the Long Run Model.

To test for the impact of the direction of the disequilibrium, a dummy variable is created that indicates when the error from the long run model is positive, $u_{\mathrm{t}-1}>0$, and is interacted with the long run error, $u \mathrm{t}-1$, to create the variable $\left(u_{\mathrm{t}-1}>0\right)^{*} u_{\mathrm{t}-1}$. Therefore, the error correction coefficient is additive for time periods when the rents are above equilibrium (rents are too high). The results indicate that for office property there is an error correction of 13.2\% for negative deviations and an error correction of $20.7 \%$ for positive deviations. This indicates that office rents may be stickier up than down. The same pattern is found for industrial space. For retail and flex space no asymmetry is found. In panel III, the results provide no consistent support for the notion that changes in demand or supply have differential impacts depending on whether rents are too high or too low.

If rents deviate substantially from equilibrium, the market may react more strongly and move rents back to equilibrium at a quicker pace. To test for this impact, a variable called $(B i g u)_{t-1}$ is created. $(B i g u)_{t-1}$ equals one when $u_{\mathrm{t}-1}$ is more than one standard deviation from the mean of $u_{\mathrm{t}-1}$, which is zero. Therefore, the coefficient on [ $\left.(\text { Big } u)_{\mathrm{t}-1} * u_{\mathrm{t}-1}\right]$ is additive to $u_{\mathrm{t}-1}$ for large deviations from equilibrium. In panel IV, the sign on [(Big $\left.\left.u\right)_{\mathrm{t}-1} * u_{\mathrm{t}-1}\right]$ is negative and statistically significant for industrial and flex properties. Therefore, there is some support for the hypothesis that larger deviations from equilibrium will lead to a faster return to equilibrium. Panel $V$ asks whether supply or demand changes have different impacts if rents are a long way from equilibrium. The interaction of a big error and supply, $\left[(B i g u)_{t-1} * \Delta \ln (s)_{t}\right]$, is negative for all property types and statistically significant for industrial and flex properties, providing some support for the notion that supply changes are more important when the rental market is very far from equilibrium. The interaction of a big error and economic activity, $\left[(B i g u)_{t-1} * \Delta \ln (E A)_{t}\right]$, is inconsistent across the property types. ${ }^{\text {Footnote21 }}$

\section{Conclusion}

Empirical studies of rent dynamics have been hampered by the lack of available data for long time series, for large cross sections, and for certain property types. Most of the prior literature has examined only a few large cities in Europe and the US. In addition, most research has been limited to the office and occasionally the retail sectors. In this paper, we provide evidence on real rent dynamics in 34 metropolitan areas in the US and on office, retail, industrial, and flex space in a unified framework and consistent data source, Costar, covering at most the second quarter of 1990 through the second quarter of 2009.

The results indicate that while there are many similarities in how different property types respond to economic activity and the supply/availability of space, there is substantial heterogeneity in long run and short run dynamics. Various tests are conducted to identify potential causes of the heterogeneity. For example, in the long run rents in metropolitan areas with less land available for development are more responsive to demand conditions. Rents also tend to be higher when lending conditions tight. This presumable reflects tougher debt coverage ratio requirements (net operating income/debt service) for refinancing. In addition, in the long run, the impact of supply is more consistent for higher quality property types.

In the short run dynamics portion of the results we find that the office market is the slowest to return to equilibrium at a rate of approximately $17 \%$ per quarter. Retail, industrial, and flex space markets move quickly back to equilibrium at rates of 28 to $48 \%$ per quarter. Therefore, after deviating from the long run equilibrium, and taking into consideration compounding, we should expect industrial property to be at long run equilibrium in less than 2 quarters, flex and retail property in less than 3 quarters, and office property in less than 5 quarters.

However, the speed of adjustment back to equilibrium is much faster within a specific quality-property type than when considering the whole market for the property type. This impact is most profound for office property where the speed of adjustment increases from 17.0 to $70.5 \%$ per quarter depending on the specification. 
Additional heterogeneity is found when considering the direction and size of the disequilibrium. For example, when rents are very far from equilibrium, changes in supply tend to have a larger impact on rents in the short run. There is also some evidence that when the disequilibrium is very large the market approaches equilibrium more quickly, regardless of the direction of the error. In addition, in the office and industrial space markets, there is evidence that rents move more quickly down than up when out of equilibrium. This likely reflects the ability of renters to renegotiate when market rents decline below existing contract rents and the inability of landlords to renegotiate when market rents are above existing contract rents.

\section{Notes}

1. For many of the metropolitan areas the data does not start until later. On average the first year with data is 1999 for office, industrial and flex property and 2001 for retail property. The last quarter with data is always the second quarter of 2009.

2. Commercial property rents have also been studied at a micro or property level using either a hedonic or repeat sales framework (Wheaton et al. 2009; Jennen and Brounen 2009; Slade 2000; Munneke and Slade 2000, 2001) and in a structural and stock adjustment framework (Benjamin et al. 1998; Wheaton et al. 1997).

3. The TWR rent index is estimated from a hedonic model using transactions from CB Commercial. The hedonic model controls for size of the building, length of the lease, height of the building, if it is a new building, and if the lease is a gross lease. These rents could reasonably be described as more constant quality than a simple average, which is what the Costar data provides. Conventions in space and across property type lead to fairly homogeneous lease types, at least on average. However, the Costar rents may be biased upward if the quality of the property is increasing over time or biased downward if the property quality is decreasing over time. These biases should lead to a more noisy measure of rental rate growth patterns.

4. Over our sample period and metropolitan areas, the percentage of space available for rent that is being marketed as sublet space is on average $8.4 \%$ for office property, $3.4 \%$ for retail property, $5.2 \%$ for industrial property, and $6.6 \%$ for flex property.

5. This Hendershott and coauthors error-correction formulation is somewhat different from the classic ECM but it is typical of the empirical literature on commercial property rent dynamics and asymmetric price adjustment. Error correction has been applied in many studies to real estate (Miller et al. 2011) consumption (Lewis 2011; Borenstein et al. 1997; Davidson et al. 1978), macroeconomics and financial markets (Garratt et al. 2003; Lastrapes and McMillin 2004) and strategic interactions among firms (Gilligan and Sarkar 1998).

6. Office employment is calculated from the following 2002 North American Industry Classification System (NAICS) and downloaded from the Bureau of Labor and Statistics web site: 50510000 Information, 55520000 Finance and Insurance, 55530000 Real Estate and Rental and Leasing, 60540000 Professional, Scientific, and Technical Services, 60550000 Management of Companies and Enterprises, 60560000 Administrative and Support and Waste Management and Remediation Services, 65610000 Educational Services, 65620000 Health Care and Social Assistance, 90000000 Government. Retail employment corresponds to 42000000 Retail Trade. Industrial employment is the addition of 30000000 Manufacturing and 43493000 Warehousing and Storage. Finally, flexible-space employment is estimated as office plus industrial employment.

7. Specification tests were also conducted using the Monthly Wholesale Trade Survey, and the Manufacturers' Shipments, Inventories, and Orders Survey to proxy for output in office, industrial, and flex property using businesses. However, the results were often counter intuitive and very sensitive to the specification. Therefore, they have not been reported in the paper.

8. NNN indicates that the tenant pays the operating expenses. Full service or gross rents indicate that the landlord pays the operating expenses. In practice, many gross leases are modified so the tenant and 
landlord share the expenses. Some net lease rates, especially in retail, increase as the tenant sells more (percentage leases).

9. Changes in the rental rate may or may not be explicitly defined in the lease. For example, a rent schedule can indicate step ups in rents for the full term of the lease on specific dates (usually every year).

Alternatively, rents could be indexed to a cost of living index such as the Consumer Price Index. Rents could even depend on how much the tenant sells, with the rent defined in part as a percentage of the sales (percentage rents).

10. Concessions can be used to ease moving costs, strategically time cash flows, or enhance the value of private information in a thin market. Typically the asking rent is publicly known while concessions are not, perhaps to improve the landlord's bargaining positions.

11. We would like to thank William Wheaton for providing us with the national TWR rent series.

12. This may also due to other factors such as market coverage in space and the quality of the space.

13. The excluded metropolitan area is Atlanta-Sandy Springs-Marriett, GA.

14. There is a possibility that the cointegration is conditional on unobserved non-stationary factors such as increased use of on-line shopping, increased offshoring of manufacturing, and increased outsourcing of service jobs that would occupy office space. These factors could lead to dynamic changes to the underlying equilibrium. Unfortunately, the relatively short time series does not allow us to test this potential issue. However, we note that Fig. 1 does not show any downward trend in real rents.

15. On average, the coefficient for economic activity and the standard error are 0.486 and 0.351 for office, 0.406 and 0.288 for retail, 0.824 and 0.238 for industrial, and 0.807 and 0.933 for flex. On average, the coefficient for supply and the standard error are -1.613 and 0.427 for office, 1.416 and 0.334 for retail, 1.769 and 0.733 for industrial, and -0.025 and 0.726 for flex.

16. While regulations in housing markets is not the same as regulations in commercial property markets it may still function as a reasonable proxy for locations that tend to regulate more or less property markets.

17. Retail property does not report grades.

18. The long run results are not reported to save some space, but are available from the authors upon request.

19. The availability of credit could also play a role in determining the long run rental rate. The long run model was rerun using the quarterly Federal Reserve Board's Senior Loan Officer Opinion Survey on Bank Lending Practices. The variable included was the net percentage of banks tightening standards for commercial and industrial loans to large and middle-market firms. With this variable included the point estimates and precision of the results were similar. The impact of more banks tightening lending standards was associated with higher long run rents on the vast majority of metropolitan areas. This likely reflects the need of landlords to have better cash flows when trying to refinance or rollover mortgage debt due to higher debt coverage ratio requirements (cash flow/debt payment). The detailed results are available from the authors.

20. It may be difficult to identify the equilibrium with few observations; therefore, the short run model was rerun using only areas with more than 40 observations. The results were qualitatively very similar to those reported in Table 9 . The effect of $E A$ was slightly higher for all property types. The short run model was also rerun including a measure of the tightness of lending standards. The results are again very similar, but the speed of adjustment is a little faster, there is a little more persistence, and $\Delta \ln (E A)$ is a little larger. In addition, for 3 of the 4 property types, the impact of more tight lending standards increased rents in the short run.

21. Two additional specification tests were conducted. The first test lags EA and $s$ and the second test weights each observation by the amount of space it represents. Both set of results are very similar to those presented in Tables 5 and 6.

\section{References}

Benjamin, J., Jud, G. D., \& Winkler, D. T. (1998). The supply adjustment process in retail space markets. Journal of Real Estate Research, 15(3), 297-308. 
Blank, D. M., \& Winnick, L. (1953). The structure of the housing market. Quarterly Journal of Economics, 67(2), 181-208.

Borenstein, S., Cameron, C., \& Gilbert, R. (1997). Do gasoline prices respond asymmetrically to crude oil price changes? The Quarterly Journal of Economics, 112(1), 306-339.

Brounen, D., \& Jennen, M. (2009a). Asymmetric properties of office rent adjustment. Journal of Real Estate Finance and Economics, 39(3), 336-358.

Brounen, D., \& Jennen, M. (2009b). Local office rent dynamics. Journal of Real Estate Finance and Economics, 39(4), 385-402.

Bulan, L., Mayer, C., \& Somerville, C. T. (2009). Irreversible investment, real options and competition: evidence from real estate development. Journal of Urban Economics, 65(3), 237-251.

De Wit, I., \& Van Dijk, R. (2003). The global determinants of direct office real estate returns. Journal of Real Estate Finance and Economics, 26(1), 27-45.

Davidson, J. E. H., Hendry, D. F., Srba, F., \& Yeo, S. (1978). Econometric modeling of the aggregate time-series relationship between consumers' expenditure and income in the United Kingdom. The Economic Journal, 88, 661-692.

De Francesco, A. J. (2008). Time-series characteristics and long-run equilibrium for major Australian office markets. Real Estate Economics, 36(2), 371-402.

Drukker, D. M. (2003). Testing for serial correlation in linear panel-data models. The Stata Journal, 3(2), 168177.

Englund, P., Gunnelin, Å., Hendershott, P. H., \& Söderberg, B. (2008). Adjustment in property space markets: taking long-term leases and transaction costs seriously. Real Estate Economics, 36(1), 81-109.

Garratt, A., Lee, K., Pesaran, M. H., \& Shin, Y. (2003). A long run structural macroeconometric model of the UK. The Economic Journal, 113(487), 412-455.

Gilligan, T. W., \& Sarkar, S. (1998). Statistical causality and strategic behavior in industrial markets. Journal of Economics \& Management Strategy, 7(2), 183-208.

Grenadier, S. R. (2005). An equilibrium analysis of real estate leases. Journal of Business, 78(4), 1173-1213.

Hendershott, P. H., Lizieri, C. M., \& MacGregor, B. D. (2010). Asymmetric adjustment in the city of London office market. Journal of Real Estate Finance and Economics, 41(1), 80-101.

Hendershott, P. H., MacGregor, B. D., \& Tse, R. Y. C. (2002). Estimation of the rental adjustment process. Real Estate Economics, 30(2), 165-183.

Hendershott, P. H., MacGregor, B. D., \& White, M. J. (2002). Explaining real commercial rents using an error correction model with panel data. Journal of Real Estate Finance and Economics, 24(1-2), 59-87.

Holland, A. S., Ott, S. H., \& Riddiough, T. J. (2000). Role of uncertainty in investment: an examination of competing investment models using commercial real estate data. Real Estate Economics, 28(1), 33-64.

Jennen, M., \& Brounen, D. (2009). The effect of clustering on office rents: evidence from the Amsterdam market. Real Estate Economics, 37(2), 185-208.

Lastrapes, W. D., \& McMillin, W. D. (2004). Cross-country variation in the liquidity effect: the role of financial markets. The Economic Journal, 114(498), 890-915.

Lewis, M. S. (2011). Asymmetric price adjustment and consumer search: an examination of the retail gasoline market. Journal of Economics \& Management Strategy, 20(2), 409-449.

Miller, N. G., Peng, L., \& Sklarz, M. A. (2011). The economic impact of anticipated house price changesevidence from home sales. Real Estate Economics, 39(2), 345-378.

Munneke, H., \& Slade, B. (2000). Empirical study of sample-selection bias in indices of commercial real estate. Journal of Real Estate Finance and Economics, 21(1), 45-64.

Munneke, H., \& Slade, B. (2001). A metropolitan transaction-based commercial price index: a time-varying parameter approach. Real Estate Economics, 29(1), 55-84.

Petersen, M. A. (2009). Estimating standard errors in finance panel data sets: comparing approaches. Review of Financial Studies, 22(1), 435-80.

Saiz, A. (2010). The geographic determinants of housing supply. The Quarterly Journal of Economics, 125(3), 1253-1296. 
Schwartz, E. S., \& Torous, W. N. (2007). Commercial office space: testing the implications of real options models with competitive interactions. Real Estate Economics, 35(1), 1-20.

Shilling, J. D., Sirmans, C. F., \& Corgel, J. B. (1987). Price adjustment process for rental office space. Journal of Urban Economics, 22(1), 90-100.

Slade, B. A. (2000). Office rent determinants during market decline and recovery. Journal of Real Estate Research, 20(3), 357-380.

Wheaton, W., Baranski, M., \& Templeton, C. (2009). 100 years of commercial real estate prices in Manhattan. Real Estate Economics, 37(1), 69-83.

Wheaton, W., \& Torto, R. G. (1988). Vacancy rates and the future of office rents. Journal of the American Real Estate and Urban Economics Association, 16(4), 430-436.

Wheaton, W., Torto, R. G., \& Evans, P. (1997). The cyclic behavior of the greater London office market. Journal of Real Estate Finance and Economics, 15(1), 77-92.

Wooldridge, J. M. (2002). Econometric analysis of cross section and panel data. Cambridge: MIT. 